\title{
Glass Transition Behavior of Aqueous Solution of Sugar-Based Surfactants
}

\author{
Shigesaburo Ogawa ${ }^{1}$ and Shuichi Osanai ${ }^{2}$ \\ ${ }^{1}$ Kyushu University \\ ${ }^{2}$ Kanagawa University \\ Japan
}

\section{Introduction}

Since the end of previous century, the role of petroleum as a raw material of synthetic surfactant gradually deflated due to the reasons such as decreasing of the relative abundance of petroleum, leading to soared prices of petroleum and increasing of carbon dioxide emission by heavy utilization of petroleum. Instead, the industries concerning in the surfactants and detergents are focusing on the utilization of biobased feedstocks, intermediates and products. Under these circumstances, the biobased surfactants derived from carbohydrate or sugar are highlighted.

Sugar-based surfactants commonly used for household products are frequently applied in foods, cosmetics and pharmaceutical industrial region (Rybinski, von W. \& Hill . K. (1998). Hill, K. \& Rhode O. (1999). Drummond, C. J.; Fong, C.; Krodkiewska, I.; Boyd, B. J. \& Baker, I. J. A. (2003). Hill, K. \& LeHen-Ferrenbach, C. (2007).). They are less toxic, highly biodegradable, and able to be readily formulated with other components. And it is well known that their representative nature is that they have ability to aggregate in an aqueous solution as well as conventional surfactants (Warr, G. G.; Drummond, C. J.; Grieser, F.; Ninham, B. W. \& Evans, D. F. (1986). Auvray, X.; Petipas, C. \& Anthore, R. (1995). Söderberg, I.; Drummond, C. J.; Furlong, D. N.; Godkin, S. \& Matthews, B. (1995). Hoffmann, B. \& Platz, G. (2001). Kocherbitov, V. \& Söderman, O. (2003). Imura, T.; Hikosaka, Y.; Worakitkanchanakul, W.; Sakai, H.; Abe, M.; Konishi, M.; Minamikawa, H. \& Kitamoto, D. (2007). Hato, M.; Minamikawa, H. \& Kato T. (2007).). The morphology of the aggregate extends over ranges from the isotropic micelle solution to the liquid crystal such as hexagonal, cubic, lamella and sponge phases.

Numerous phase diagrams of the amphiphiles, which describe the aggregative behavior of the compound, are exhibited in terms of concentration and temperature. We are able to see those of the anionic, cationic and nonionic surfactant, but the diagram under $0{ }^{\circ} \mathrm{C}$ especially in the frozen state was not reported so much. Among such studies, cationic surfactant, octyl trimethylammonium bromide is reported to be able to lower the freezing point of ice effectively due to the presence of their ionic head group (Fukada, K.; Matsuzaka, Y.; Fujii, M.; Kato, T. \& Seimiya, T. (1998).). Similarly, nonionic surfactant such as polyoxyethylene 
glycol decyl $\left(\mathrm{C}_{10} \mathrm{E}_{\mathrm{m}} ; \mathrm{m}=4-8\right)$ and dodecyl $\left(\mathrm{C}_{12} \mathrm{E}_{\mathrm{m}} ; \mathrm{m}=5,6\right.$ and 8$)$ ether were reported to crystallize ice below $-11{ }^{\circ} \mathrm{C}$ or $-4.5^{\circ} \mathrm{C}$, respectively (Andersson, B. \& Olofsson, G. (1987). Nibu, Y.; Suemori, T. \& Inoue T. (1997). Nibu, Y. \& Inoue, T. (1998a, 1998b). Zheng, L. Q.; Suzuki, M. \& Inoue, T. (2002). Zheng, L.; Suzuki, M.; Inoue, T. \& Lindman, B. (2002).). Contrary to this, the phase diagram of sugar-based surfactant seems to be uncompleted particularly under supercooled conditions under $0{ }^{\circ} \mathrm{C}$.

Some nonionic surfactants were not used as a curative agent but a plasticizer because they showed the glass transition temperature $\left(T_{\mathrm{g}}\right)$ at low temperature region (Jensen, R. E.; O'Brien, E.; Wang, J.; Bryant, J.; Ward, T. C.; James, L. T. \& Lewis, D. A. (1998); Amim, J.; Kawano, Y. \& Petri, D. F. S. (2009).). Tween 40, poly(oxyethylene) sorbitan monopalmitate which have $20 \mathrm{EO}$ units in the molecule was reported to possess $T_{\mathrm{g}}$ at $-61{ }^{\circ} \mathrm{C}$. Triton $\mathrm{X}-100$ showed its $T_{\mathrm{g}}$ at $-59{ }^{\circ} \mathrm{C}$. Ethylene oxide surfactant such as hexahydrofarnesyl ethylene oxide surfactants $(\mathrm{EO}=1-8)$ exhibited their $T_{\mathrm{g}}$ at low temperatures below $-80^{\circ} \mathrm{C}$ (Fong, C.; Weerawardena, A.; Sagnella, S. M.; Mulet, X.; Krodkiewska, I.; Chong, J. \& Drummond, C. J. (2011).). In addition to this, there is a report that says sugar derivatives containing a hydrophobic group are applicable as a plasticizer. Gill stated that when such a sugar derivative was added to the corresponding free sugar, $T_{\mathrm{g}}$ of the mixture tended to lower than those of the free sugar system (Gill, I. \& Valivety, R. (2000a, 2000b).). Here, the sugar given hydrophobicity worked as a plasticizer for a free sugar. On the other hand, when the other component which possessed much lower $T_{\mathrm{g}}$ than that of the sugar derivative was mixed in the system, the existing sugar derivative did not necessarily work as a plasticizer.

Although it had been scarcely studied about the glass-forming property of sugar-based surfactants, but nowadays, much attention is being denoted to their interesting characteristics. It has been reported that $n$-alkyl glycosides such as a-D-glucosides, $\beta$-Dmaltosides, $\beta$-D-maltotrioside and sucrose fatty acid esters formed a glass state under anhydrous conditions (Hoffmann, B.; Milius, W.; Voss, G.; Wunschel, M.; van Smaalen, S.; Diele, S. \& Platz G. (2000). Kocherbitov, V. \& Söderman, O. (2004). Ericsson, C. A.; Ericsson, L. C.; Kocherbitov, V.; Söderman, O. \& Ulvenlund, S. (2005). Ericsson, C. A.; Ericsson, L. C. \& Ulvenlund, S. (2005). Szúts, A.; Pallagi, E.; Regdon, G. Jr; Aigner, Z.; Szabó-Révész, P. (2007).). Their $T_{\mathrm{g}}$ increased from $-12.4{ }^{\circ} \mathrm{C}$ of $n$-heptyl a-Dglucopyranoside to $100{ }^{\circ} \mathrm{C}$ of $n$-dodecyl $\beta$-D-maltotrioside in proportional to the number of saccharide unit. Thus, $T_{\mathrm{g}}$ of the sugar based surfactants are much higher than that of the other nonionic surfactants as mentioned above. That is, sugar-based surfactants possess a remarkable glass forming ability comparing to another type of surfactant. Because $T_{\mathrm{g}}$ of anhydrous sugar-based surfactant existed almost above the freezing point of water, $0^{\circ} \mathrm{C}$, therefore, we expected that the behavior and ability of making glass state of the aqueous sugar-based surfactant solution can be readily observed without ice freezing if the cooling was conducted rapidly.

Recently, authors studied the vitrification or glassification of the aqueous solution of sugarbased surfactant, which must be associated with the specific function under freezing state (Ogawa, S. \& Osanai, S. (2007). Ogawa, S.; Asakura, K. \& Osanai, S. (2010).). In this chapter, we would like to elucidate some aspects of the aqueous solution of sugar-based surfactant under supercooling, where the simple primary phase transition such as gelation and 
crystallization is not a key topic, but the vitrification plays an important role. We would like to indicate the some characteristics of the sugar-based surfactant in an aqueous solution under low temperature. The basic behavior of these surfactants solution will be focused on the following items.

- The glass transition of the aqueous solution of sugar-based surfactant under low temperature with forming thermotropic and lyotropic liquid crystalline phases.

- Correlation between the glass transition and the protective effect against freezing.

The information obtained from this chapter would be valuable to the researchers who engage the low temperature technologies.

\section{Glass transition behavior of octyl $\beta$-D-glucoside/water binary mixtures}

Octyl $\beta$-D-glucoside (G8Glu: Scheme 1) is one of the representative sugar-based surfactants. Although there are many reports on phase behavior of C8Glu/water binary system (Boyd, B. J.; Drummond, C. J.; Krodkiewska, I. \& Grieser, F. (2000). Nilsson, F.; Söderman, O. \& Johansson, I. (1996). Häntzschel,D.; Schulte, J.; Enders, S. \& Quitzsch, K. (1999). Dörfler, H.D. \& Göpfert, A. (1999). Bonicelli, M. G.; Ceccaroni, G. F. \& La Mesa, C. (1998). Sakya, P., Seddon, J. M. \& Templer, R. H. (1994). Loewenstein, A. \& Igner, D. (1991). Kocherbitov, V.; Söderman O. \& Wadsö, L. (2002).), no report was presented on its vitrification behavior under the low temperature. In this section, we introduce the glass transition behavior of octyl $\beta$-D-glucoside/water binary mixture within a wide concentration range under the conditions without ice formation (Ogawa, S.; Asakura, K. \& Osanai, S. (2010).).

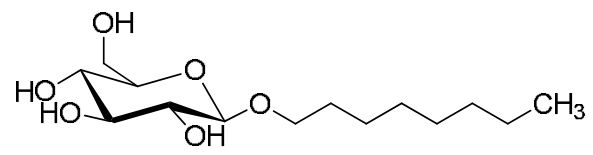

Scheme 1. Chemical structure of octyl $\beta$-D-glucoside (C8Glu).

C8Glu was synthesized as described in the literature, with a little modification (Bryan, M. C.; Plettenburg, O.; Sears, P.; Rabuka, D.; Wacowich-Sgarbi, S. \& Wong, C.-H. (2002).).

\subsection{Thermal behavior of C8Glu/water binary system}

Fig. 1 shows a typical DSC chart which illustrates the glass transition behavior of G8Glu/water mixture. Each sample with various concentrations was homogenized by heating until $120^{\circ} \mathrm{C}$ prior to the measurement. The sample was rapidly cooled to $-120^{\circ} \mathrm{C}$ at $-10{ }^{\circ} \mathrm{C} / \mathrm{min}$ and then heated at the rate of $10{ }^{\circ} \mathrm{C} / \mathrm{min}$. As Fig. 1 shows, when the concentration of C8Glu was greater than ca. $80 \mathrm{wt} \%$, no ice was produced during cooling, and the glass transition was observed during the heating process. Occurrence of the glass transition was confirmed by the discontinuity of the heat capacity as indicated by solid line arrows in Fig. 1. In the concentration range from ca. 80 to $82 \mathrm{wt} \%$ for C8Glu, the ice was formed by the devitrification and thawed in the heating process (Fig. 1(a)). Devitrification was defined as the solidification phenomena after the temperature exceeded $T_{\mathrm{g}}$ in the heating process. 


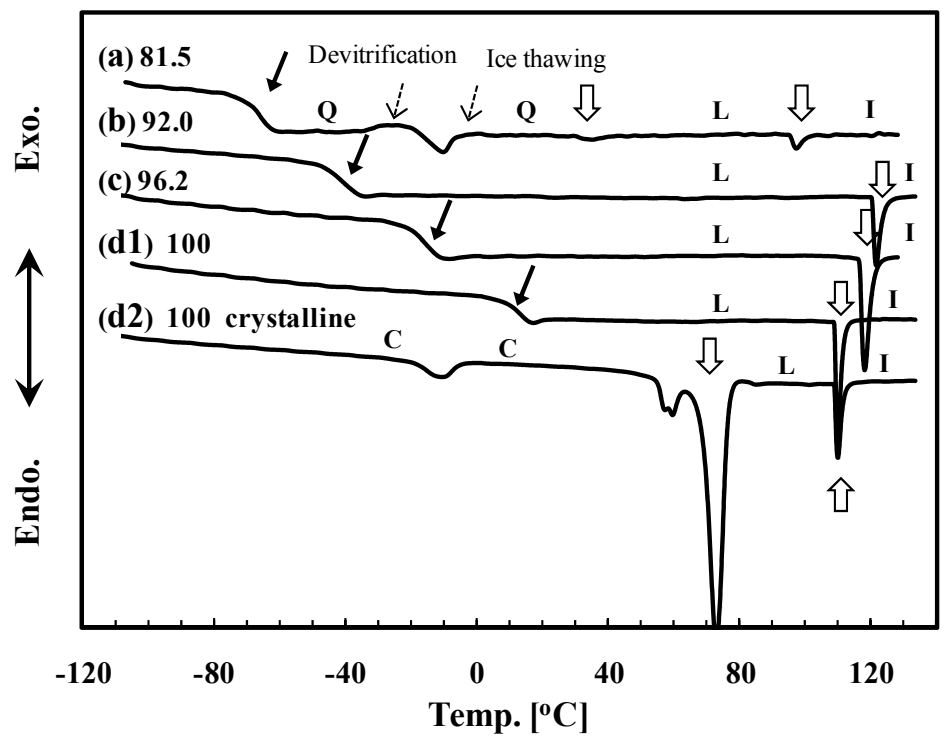

Fig. 1. Typical DSC thermograms of heating process at $10^{\circ} \mathrm{C} / \mathrm{min}$ of $\mathrm{C} 8 \mathrm{Glu} /$ water mixture.

The concentration of the sample is expressed in wt \%. White arrows indicate the phase transition between the liquid crystalline phases or from the liquid crystalline phases to an isotropic solution or melt. Solid line arrows indicate the glass transition, as mentioned above. I: isotropic solution, H: hexagonal phase, Q: cubic phase, L: lamellar phase, C: crystalline phase. Apparatus; DSC 60 (SHIMAZU Co. Ltd.) equipped with a cooling accessory was used throughout the measurement. Sample preparation; Samples of an aqueous solution were prepared from C8Glu and the prescribed amount of water. The sample was prepared as following two methods. Method A; A dilute aqueous C8Glu solution (ca. 35 $\mathrm{wt} \%$ ) in an aluminium pan was directly concentrated by drying over phosphorous pentoxide at an ambient temperature. Method B; A prescribed amount of water was absorbed under a humid atmosphere or added directly to C8Glu that was free from water. The anhydrous C8Glu was prepared by placing the sample on a hot stage at $125{ }^{\circ} \mathrm{C}$ for 50 min under a $\mathrm{N}_{2}$ atmosphere to remove any water.

G8Glu/water binary system gave various kinds of liquid crystalline (LC) phase, such as hexagonal $(\mathrm{H})$, cubic $(\mathrm{Q})$, and lamella (L) phases and crystalline phase (C) according to its concentration and temperature. Fig. 1(b) indicates that $\mathrm{L}$ phase existed after the glass transition took place at around $-40^{\circ} \mathrm{C}$ during a heating process and it changed into isotropic liquid at $120^{\circ} \mathrm{C}$. In other words, the glass transition did not occur in crystalline and isotropic liquid phases but in a LC phase during the cooling process. A detailed comparison of (d1) with (d2) in Fig.1 clearly demonstrated that the phase transition from glass to lamella occurred in the LC phase, because the peak due to the transformation from crystalline to lamella LC at $70{ }^{\circ} \mathrm{C}$ was not observed in (d1) chart.

Observation by the polarizing optical microscopy (POM) gave a consistent result with these findings mentioned above. The sample was rapidly cooled to $-100{ }^{\circ} \mathrm{C}$ at $-10{ }^{\circ} \mathrm{C} / \mathrm{min}$ and 
then heated at the rate of $10{ }^{\circ} \mathrm{C} / \mathrm{min}$. Fig. 2 shows the POM images of the C8Glu sample solution. Its conditions are shown in a legend of the figure. As can be seen from Fig. 2a and $2 \mathrm{~b}$, the $\mathrm{L}$ texture exhibited oily streaks at both temperatures above and below $T_{\mathrm{g}}$. It indicated that $\mathrm{L}$ phase texture was maintained above or below $T_{\mathrm{g}}$. It presented unambiguous evidence that this sample changed from liquid crystal to a glassy phase with holding its lamella structure, that is, the "glassy liquid crystals". The basic concept of the glassy liquid crystal was introduced in references. (Yoshioka, H.; Sorai, M. \& Suga, H. (1983). Kocherbitov, V. \& Söderman, O. (2004).
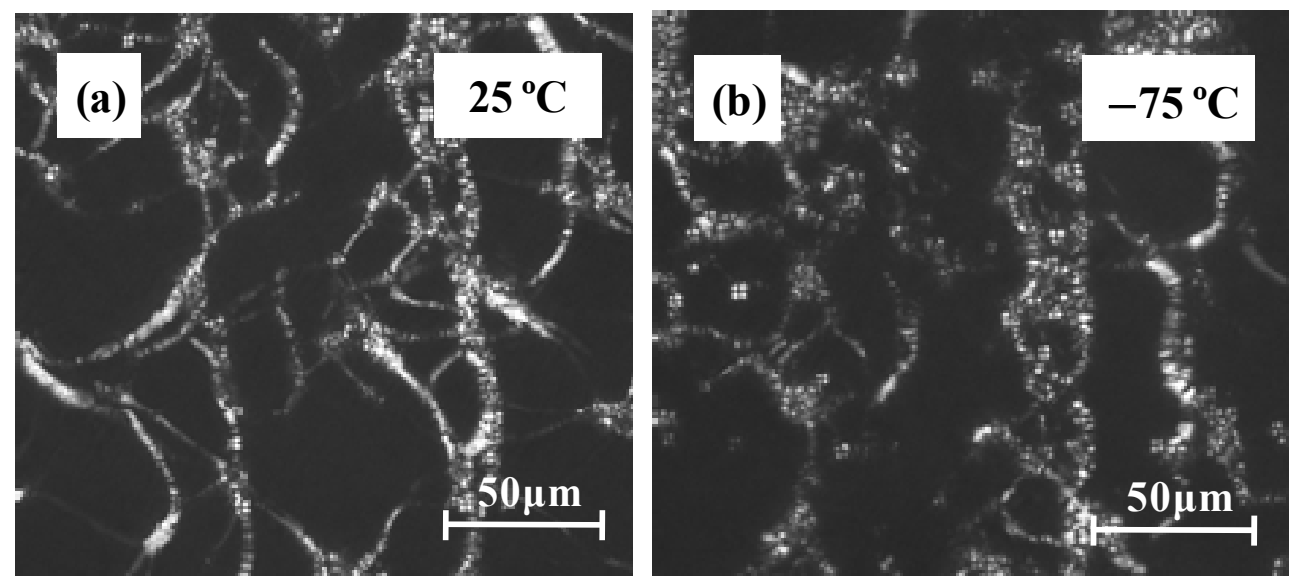

Fig. 2. POM photographs of $92.5 \mathrm{wt} \%$ of $\mathrm{C} 8 \mathrm{Glu} /$ water mixture above and below $T_{\mathrm{g}}$ of $-47^{\circ} \mathrm{C}$.

Apparatus; Polarizing microscopy (BH-51, Olympus) equipped with a heating/cooling stage was used for observation. Sample preparation; Sample solutions were prepared in a similar manner to the DSC measurement. Sample was observed through a thin specimen sandwiched between a slide plate and cover-glass plate.

\subsection{Concentration-temperature phase diagram with $T_{\mathrm{g}}$ curve}

Fig. 3 is a phase diagram of the C8Glu/water binary system at concentrations of more than $50 \mathrm{wt} \%$. The diagram was constructed on the basis of experimental results obtained from DSC thermograms and POM photographs. Interested readers are able to refer detail methods for the determination of LC phases from numerous references as mentioned at the beginning of this section.

In this diagram, $T_{\mathrm{g}}$ curve, the ice nucleation temperature curve (INC), and devitrification temperature curve (DC) are depicted. Although INC and DC curves are variable parameter according to the rate of nucleation, they are useful to understand the dynamic behavior of the system. As shown in Fig. 3, as the concentration of C8Glu increases, the lyotropic aggregates change from an isotropic solution (Micelle solution: $\mathrm{M}$ ) to the liquid crystal phase, such as, $\mathrm{H}, \mathrm{Q}$, and $\mathrm{L}$ phases at $0{ }^{\circ} \mathrm{C}$. When the concentration of C8Glu was lower than $80 \%$, the INC was clearly recognized. It meant that the crystallization preferentially occurred below this temperature before the vitrification took place. 
A lot of reference showed phase diagrams of C8Glu/water system that expressed the existence of crystal phase or gel phase in the concentrated region over $90 \mathrm{wt} \%$. But in our study, the crystal phase did not appear in the same concentration at cooling rate -10 ${ }^{\circ} \mathrm{C} / \mathrm{min}$, between $-120^{\circ} \mathrm{C}$ and $120^{\circ} \mathrm{C}$. Instead of that, the glass transition was observed over ca. $80 \mathrm{wt} \%$ concentration. That was referred to $T_{\mathrm{g}}$ curve in Fig. 3. The glass transition temperature, $T_{\mathrm{g}}$, shifted to higher, as the concentration of C8Glu moved to higher. It means that C8Glu did not work as a plasticizer but as a curative agent in an aqueous solution.

Comparing the phase diagram above and below $T_{\mathrm{g}}$ curve in Fig. 3, we are able to understand that the glassy phase was formed by cooling both of $Q$ and L phases. It could therefore be presumed that, the formation of $Q$ and L types of glassy LC phase occurred below $T_{\mathrm{g}}$ curve. Even if temperature crossed the phase boundary between the $\mathrm{Q}$ and $\mathrm{L}$ phases, there was no discontinuity in $T_{\mathrm{g}}$ line. It suggested that the difference among the liquid crystalline structures was not a decisive factor for the determination of $T_{\mathrm{g}}$ in the aqueous solution.

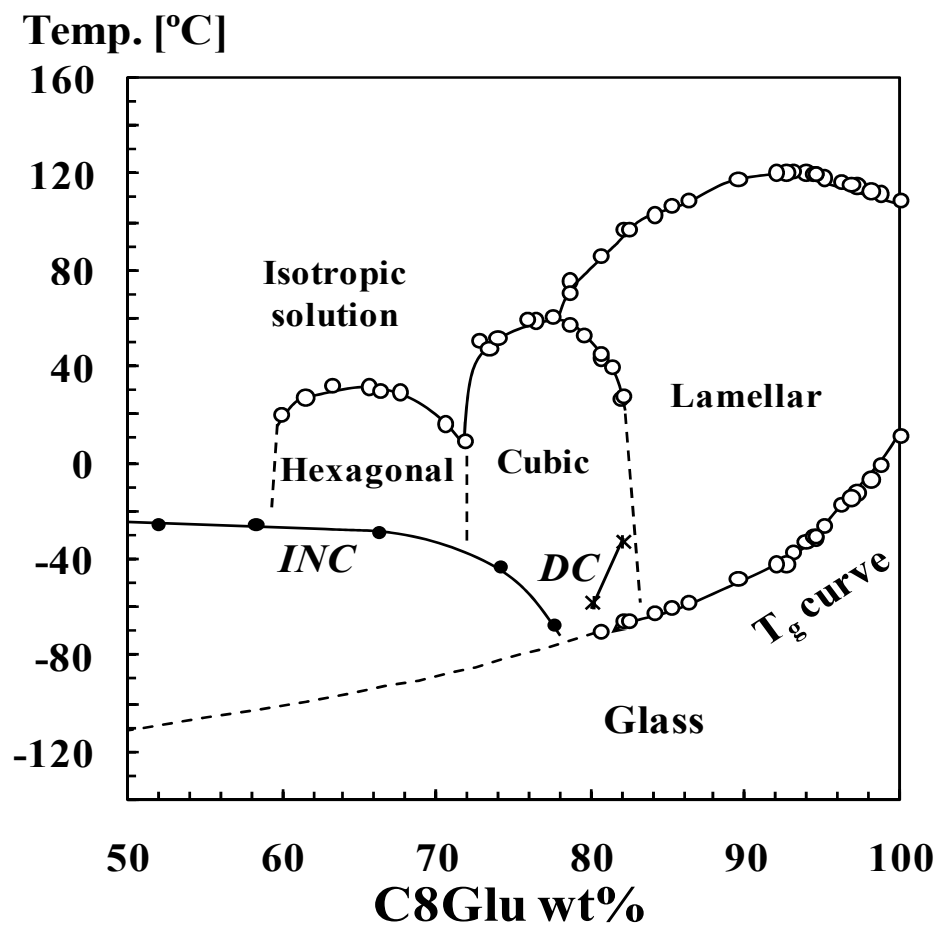

Fig. 3. Phase diagram of C8Glu/water mixture from 50 to $100 \mathrm{wt} \%$ C8Glu concentration including $T_{\mathrm{g}}$ curve, ice nucleation curve (INC) and devitrification curve (DC).

The dotted lines are predicted one. The phase transition temperatures were determined by the intersection of the baseline and tangent to the end of the endothermic peak of the DSC chart on heating. $T_{\mathrm{g}}$ was determined as the temperatures corresponding to half of the magnitude of the heat capacity change $\left(\Delta C_{\mathrm{p}}\right)$ at $T_{\mathrm{g}}$ (Blond, G.; Simatos, D.; Catté, M.; Dussap, 
C. G.; Gros, J. B. (1997).). The ice crystallization temperatures were defined as the average of five measurements.

\subsection{Comparison of glass transition behavior with predicted curve}

Couchman and Karasz presented a model that predicts $T_{\mathrm{g}}$ of a mixture employing classical thermodynamics (Couchman, P. R. \& Karasz, F. E. (1978). Couchman, P. R. (1978).). This model treated the glass transition as if it was equivalent to an Ehrenfest second order transition. The "original" Couchman-Karasz (C-K) formula is given below:

$$
\ln T_{g}=\frac{x_{1} \ln T_{g 1}+k x_{2} \ln T_{g 2}}{x_{1}+k x_{2}}
$$

where the subscripts 1 and 2 denote components 1 (C8Glu) and 2 (pure water), respectively. The symbols $x_{1}$ and $x_{2}$ represent the mole fractions of the corresponding C8Glu and pure water, respectively. $T_{\mathrm{g}}$ is the glass transition temperature of the mixture under consideration; $k$ is a constant defined as $\Delta C_{\mathrm{p} 2} / \Delta C_{\mathrm{p} 1} . \Delta C_{\mathrm{p} 1}$ and $\Delta C_{\mathrm{p} 2}$ are the $\Delta C_{\mathrm{p}}$ at $T_{\mathrm{g}}$ of component 1 , pure solute and component 2, pure water, respectively. Eq. 1 is often "modified" to the following general form:

$$
T_{g}=\frac{x_{1} T_{g 1}+k x_{2} T_{g 2}}{x_{1}+k x_{2}}
$$

The suitability of these two equations ("original" and "modified" C-K equations) was discussed by comparison with the actual experimental measurements for $T_{\mathrm{g}}$ of the G8Glu/water mixture.

Fig. 4 shows the $T_{\mathrm{g}}$-prediction curves obtained from the "original" and "modified" C-K equations, using $\Delta C_{\mathrm{p} 1}=142.2 \mathrm{~J} / \mathrm{mol} \mathrm{K}$ at $T_{\mathrm{g} 1}=284.4 \mathrm{~K}\left(11.2^{\circ} \mathrm{C}\right)$ for the amorphous C8Glu as obtained from our experimental results. At the same time, the experimental values were indicated in the corresponding figures. Values of $\Delta C_{\mathrm{p} 2}=35.0 \mathrm{~J} / \mathrm{mol} \mathrm{K}$ and $T_{\mathrm{g} 2}=135 \mathrm{~K}$ $\left(-138.2^{\circ} \mathrm{C}\right.$ ) for the pure water were taken from the literatures (Sugisaki, M.; Suga, H. \& Seki, S. (1968). Rasmussen, D. H. \& MacKenzie, A. P. (1971).). The experiment indicated that the analysis using the "original" (Eq. 1) gave a relatively good agreement with the experimental result over the entire concentration studied. By contrast, the predicted $T_{\mathrm{g}}$ obtained from the "modified" (Eq. 2) (dotted line) was not in accord with the experimental finding. By considering these results, we can state the "original" C-K equation would give a much better prediction than the "modified" one for $T_{\mathrm{g}}$ determination in mixtures. Couchman stated that if the assumption that $T_{\mathrm{g} 1} / T_{\mathrm{g} 2} \approx 1$ was applicable, the results obtained using the "modified" C-K would be valid (Couchman, P. R. \& Karasz, F. E. (1978).). In our system, $T_{\mathrm{g} 1}$ of anhydrous C8Glu is $284.4 \mathrm{~K}$, and giving a $T_{\mathrm{g} 1} / T_{\mathrm{g} 2}$ for C8Glu of 2.11 . This value is far from the unity that is appropriate for the "modified" C-K equation. We guessed that the $T_{\mathrm{g}}$ ratio between two components which form the mixture must be approximately one if we want to employ the 'modified' C-K equation to predict $T_{\mathrm{g}}$.

$$
\begin{gathered}
\Delta C_{p}[J / g K]=\Delta F /\left(W_{\text {sample }} \times \text { scan rate }\right) \\
\Delta C_{p}[J / \operatorname{mol} K]=\Delta C_{p}[J / g K]\left(M W_{1} \times x_{1}+M W_{2} \times x_{2}\right)
\end{gathered}
$$


where $W_{\text {sample }}$ is the sample weight in a sealed pan and $\Delta F$ is the heat flow change (Fig. $4 \mathrm{~b}$ ). $M W_{1}$ and $M W_{2}$ are the molar weight of C8Glu [MW $\left.: 292.19\right]$, and pure water [ $\left.M W_{2}: 18.02\right]$.

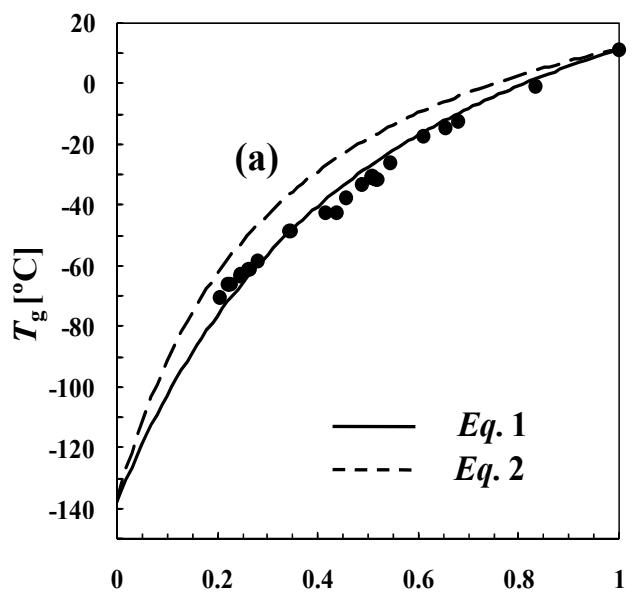

C8Glu mole fraction

(b)

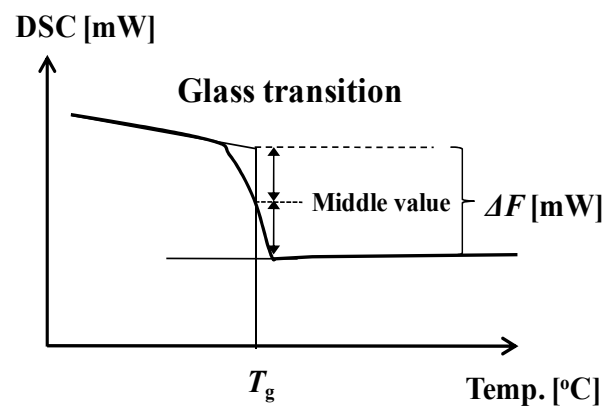

Fig. 4. (a) Comparison of experimental $T_{\mathrm{g}}$ of C8Glu/water mixture obtained by two kinds of predicted curves by $\mathrm{C}-\mathrm{K}$ equations and (b) estimation of $T_{\mathrm{g}}$ and $\Delta F$.

Each plot shows the experimental data. $\Delta F$ was determined as sketched in Fig.4(b). Using this parameter, $\Delta C_{\mathrm{p}}$ was obtained as follows.

\subsection{Influence of concentration on $\Delta C_{\mathrm{p}}, \Delta H$ and phase transition temperature $T_{\mathrm{g}}$}

Fig. 5 shows the $\Delta C_{\mathrm{p}}$ curve as a function of the mole fraction of C8Glu. As mole fraction is decreasing from 1.0, there were two bending points at 0.65 and 0.40 . The curve is divided into three regions (A, B, and $\mathrm{C}$ ) according to their characteristics.

In the mixture of $\mathrm{C} 8 \mathrm{Glu} /$ water, $\Delta C_{\mathrm{p}}$ for pure water $\left(\Delta \mathrm{C}_{\mathrm{p} 2}\right)$ obtained by extrapolation of the plots in region $\mathrm{C}$ to zero $\mathrm{C} 8 \mathrm{Glu}$ content, was $35.0 \mathrm{~J} / \mathrm{mol} \mathrm{K}$. This value is compatible with the experimental value reported by Sugisaki et al. (Sugisaki, M.; Suga, H. \& Seki, S. (1968).). On the other hand, $\Delta C_{\mathrm{p}}$ for pure C8Glu $\left(\Delta C_{\mathrm{p} 1}\right)$ obtained by extrapolation of the plots in region $\mathrm{C}$ to $1.0 \mathrm{C} 8 \mathrm{Glu}$ content, was about $175 \mathrm{~J} / \mathrm{mol} \mathrm{K}$. There was an apparent difference between the extrapolated and actual experimental value, $142.2 \mathrm{~J} / \mathrm{mol} \mathrm{K}$. By contrast, the extrapolation of plots in region A reached $0 \mathrm{~J} / \mathrm{mol} \mathrm{K}$. These results showed that $\Delta C_{\mathrm{p}}$ of the binary mixture was not predictable using a simple linear function composed of $\Delta C_{\mathrm{p} 1}$ and $\Delta C_{\mathrm{p} 2}$.

In order to obtain information for clarification of this complex behavior of $\Delta C_{p}$, the transition between lamella and isotropic liquid phases were studied further in detail.

Fig. 6 indicates the relationships of the phase transition between lamella (L) and isotropic solution (I) with C8Glu mole fraction. Enthalpy $(\Delta H)$ and temperature of the phase transition are depicted on the two vertical axes. Generally speaking, enthalpy of C8Glu solution decreased as the mole fraction of C8Glu reduced. A clear bending point was recognized at a particular 
concentration with mole fraction of 0.65 , which was in fair agreement with that of the first bending point shown in Fig. 5. The enthalpy of the system reached $0 \mathrm{~J} / \mathrm{mol}$ by extrapolation of plots in region $\mathrm{A}$ in analogy with the result shown in Fig. 5. These results meant that the amount of water in region A would have no influence not only on $\Delta C_{p}$ but also on $\Delta H$.

Here, we adopted a concept of the "non-continuous water" to propose a hypothesis that interprets above behavior of $\Delta C_{\mathrm{p}}$ in $\mathrm{C} 8 \mathrm{Glu}$ / water mixture.

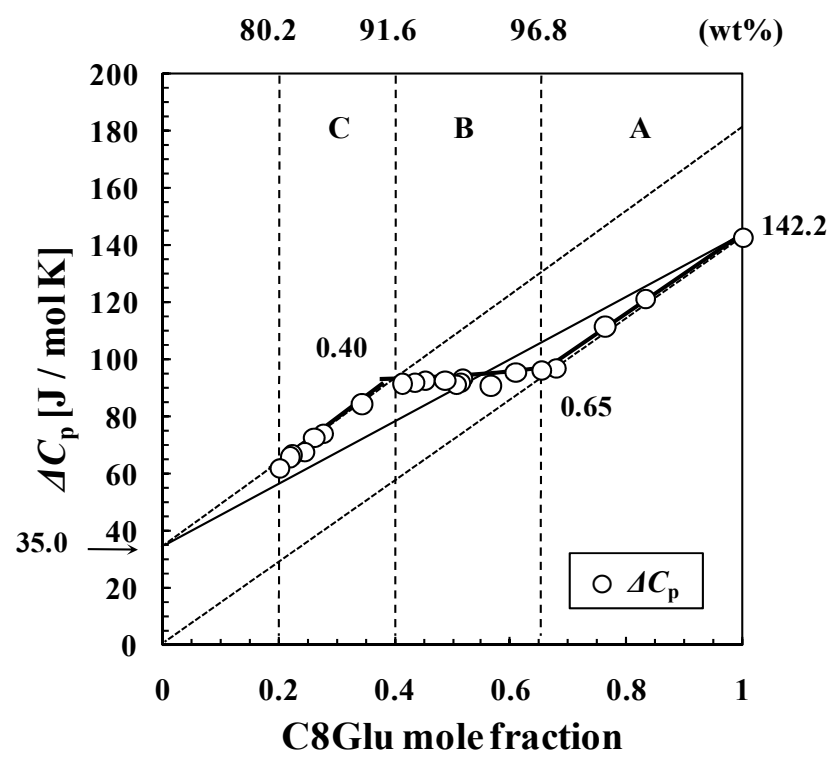

Fig. 5. $\Delta C_{\mathrm{p}}$ behavior of $\mathrm{C} 8 \mathrm{Glu} /$ water mixture with variation in concentrations.

The linear solid line connecting two $\Delta C_{\mathrm{p}}$ values, 35.0 and 142.2 shows $\Delta C_{\mathrm{p}}$ line when the mixing was carried out under holding ideal state.

We interpreted the behavior of C8Glu in different concentration of aqueous solution as follows: Fig. 7 shows the relationships among $\Delta C_{\mathrm{p}}$ at $T_{\mathrm{g}}, \Delta H$ of the phase transition and the phase transition temperature in $\mathrm{C} 8 \mathrm{Glu}$ /water mixture systems on the basis of the experimental results. In region C, the molar ratio of water: C8Glu was $1.5: 1-4: 1$, that is, molecule's number of water is larger than that of the C8Glu. The water in this region will constitute the aqueous phase keeping continuous state among a bimolecular membrane lamellar structure. It is a kind of bulk water. Reduction of water means simple decrease of the bulk water stated above. The fact that extrapolation of plots of $\Delta C_{\mathrm{p}}$ in region $\mathrm{C}$ reached $35 \mathrm{~J} / \mathrm{mol} \mathrm{K}$ and coincided with that of pure water proved its validity.

On the other hand, in region A, the molar ratio of water : C8Glu is $1: 2$. In other words, the number of water molecule is less compared with that of C8Glu. The scarcity of water will be further signalized by consideration of their relative magnitude of the molecular bulkiness. This circumstance will not enable the water molecule to exist in continuous state. The water molecules in region A would be present in a non-continuous state with creating a new hydrogen bond among the glucoside molecules. 


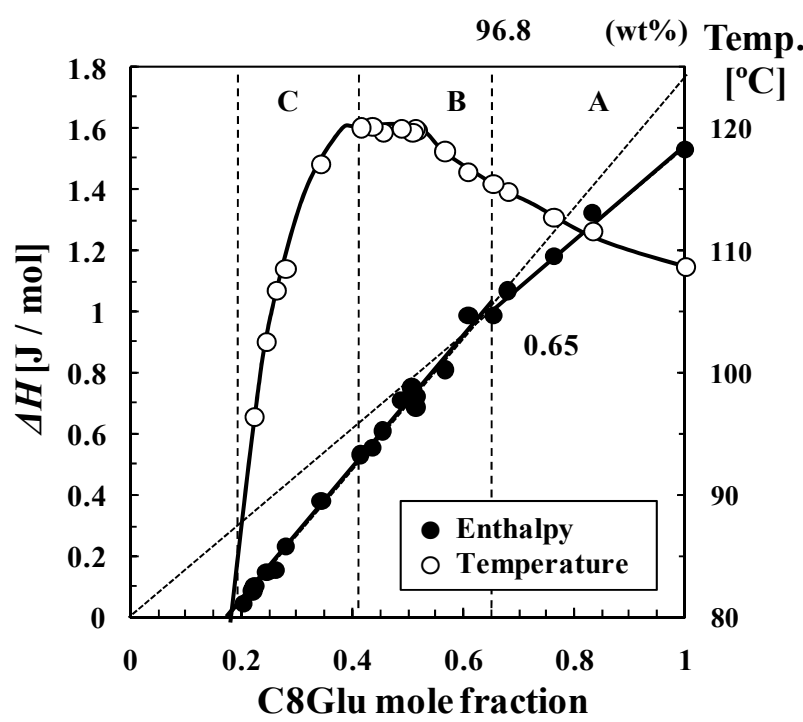

Fig. 6. Relationships of phase transition behavior between lamellar phase and isotropic solution with C8Glu fraction.

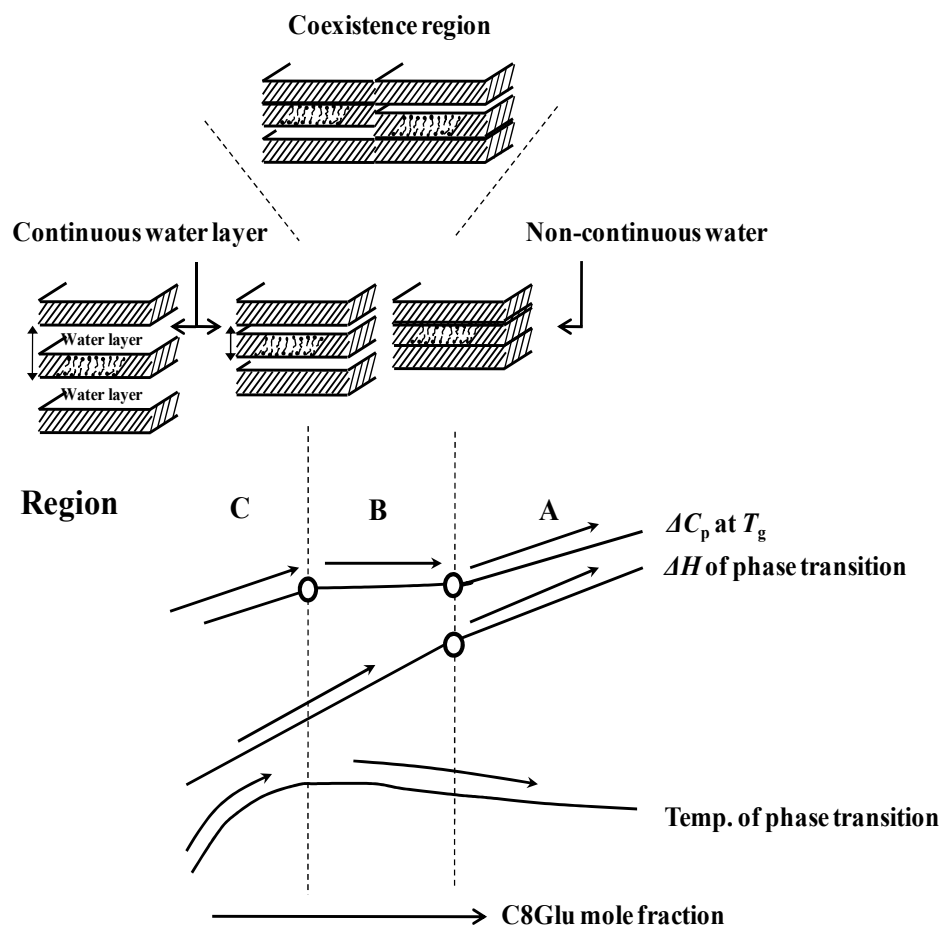

Fig. 7. Schematic figure of C8Glu/water mixture systems with variation of C8Glu concentration. 
Region A: The water molecules would be present in a non-continuous state.

Region B: The water characteristic is determined by the mixed system composed of the continuous and non-continuous water existed in the region $\mathrm{C}$ and $\mathrm{A}$.

Region C: The water behaves like bulk water and constitutes the aqueous phase keeping continuous state among a bimolecular membrane lamellar structure. Reduction of water means simple decrease of the bulk water.

In region $B, \Delta C_{p}$ kept in a constant state irrespective of its concentration of the system. This result demonstrated the additivity of two kinds of states at the corresponding concentration of the bending points in Fig. 5. It means the behavior of water in this region would be determined by the mixed system composed of the continuous and non-continuous water existed in the region $\mathrm{C}$ and $\mathrm{A}$, respectively.

\section{Glass transition behavior of octyl $\beta$-D-glucoside/ $\mathrm{NaCl} /$ water ternary mixtures}

The aqua-system of the life organism contains a various kinds of ions and exhibits complicated buffer actions to maintain its physiological functions in a normal state. As it is cooled down, eutectic phase composed of electrolyte and ice was generated in the concentrated unfrozen phase (Mullin, J. W. (2001).). Occurrence of the eutectic would be responsible of direct causes for damages against cells and enzymes and resulted unusual $\mathrm{pH}$ change would become a trigger for abnormal interactions (Heber, U.; Tyankova, L. \& Santariu, K. A. (1971). Mollenhauer, A.; Schmitt, J. M.; Coughlan, S. \& Heber U. (1983). Han, B. \& Bischof, J. C. (2004). Wang, C.-L., Teo, K. Y. \& Han. B. (2008). Goel, R.; Anderson, K.; Slaton, J.; Schmidlin, F.; Vercellotti, G.; Belcher, J. \& Bischof, J. C. (2009).). In actual circumstances where the life organisms are treated under extremely and mildly cool atmosphere, various kinds of cryoprotectants and lyoprotectants such as salts, amino acids, carbohydrates, artificial and natural polymers are used to stabilize these bio-tissues from the cooling damages (Heber, U.; Tyankova, L. \& Santariu, K. A. (1971). Tyankova, L. (1972). Izutsu, K.; Yoshioka, S. \& Kojima, S. (1995). Koshimoto, C. \& Mazur, P. (2002). Chen, N. J.; Morikawa, J. \& Hashimoto, T. (2005). Chen, Y.-H. \& Cui, Z. (2006). Kawai, K. \& Suzuki, T. (2007). Izutsu, K.; Kadoya, S.; Yomota, C.; Kawanishi, T.; Yonemochi, E. \& Terada, K. (2009).).

The purpose of this section is to clarify the inhibition effect of sugar-based amphiphiles on eutectic formation in the freeze-thawing process of aqueous $\mathrm{NaCl}$ solution (Ogawa, S. \& Osanai, S. (2007).).

\subsection{Thermal behavior of sugar-based amphiphiles/ $\mathrm{NaCl} /$ water ternary system}

Fig. 8 shows DSC charts of the ternary system consist of $\mathrm{C} 8 \mathrm{Glu} / \mathrm{NaCl} /$ water. A solution containing C8Glu at the same concentration (C8Glu to water $=1: 9$ [wt $\%]$ ) was mixed with various concentration of $\mathrm{NaCl}$ as shown in Fig. 8. Each sample was cooled to $-100{ }^{\circ} \mathrm{C}$ at -10 ${ }^{\circ} \mathrm{C} / \mathrm{min}$ and then heated at the rate of $3{ }^{\circ} \mathrm{C} / \mathrm{min}$. The peak appeared at $-21^{\circ} \mathrm{C}$ referred to the fusion peak of eutectic of $\mathrm{NaCl} \cdot 2 \mathrm{H}_{2} \mathrm{O} /$ ice and another peak at about $0{ }^{\circ} \mathrm{C}$ was that of ice (Hvidt, A. \& Borch, K. (1991).). These samples were classified into three groups according to the concentration of $\mathrm{NaCl}$, Group I, II and III. 


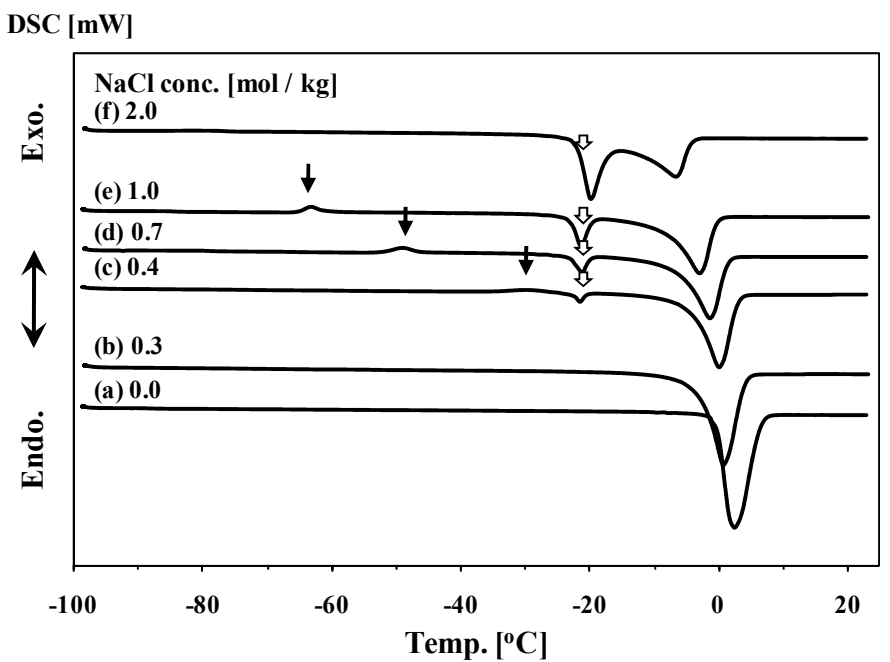

Fig. 8. DSC thermograms of $\mathrm{C} 8 \mathrm{Glu} / \mathrm{NaCl} /$ water systems in the thawing process at the heating rate of $3{ }^{\circ} \mathrm{C} / \mathrm{min}$.

The weight ratio between C8Glu and water was constant (C8Glu : water $=10: 90 \mathrm{wt} \%$ ). $\mathrm{NaCl}$ concentrations were shown in the figure. Apparatus; DSC 60 (SHIMAZU) was used throughout. Sample preparation; Each sample was prepared by dissolving $\mathrm{NaCl}$ and the C8Glu in a prescribed amount of water and leaving to stand for at least $2 \mathrm{~h}$.

Group I: Chart (a) and (b) in Fig. 8. Their $\mathrm{NaCl}$ concentration was low. Only one peak due to fusion of ice was noticeable, that is, formation of the eutectic was completely restrained.

Group II: Chart (c), (d) and (e). Concentration of $\mathrm{NaCl}$ was moderate. The exothermic peak due to devitrification was also observed in addition to the peaks due to fusion of ice and eutectic were observed.

Group III: Chart (f). Concentration of $\mathrm{NaCl}$ was high. Only two peaks due to fusion of the eutectic and ice were observed and the devitrification was not recognized. The exothermic peak due to devitrification was also observed in addition to the peaks due to fusion of ice and eutectic.

\subsection{Analysis of enthalpy for the fusion of eutectic and ice}

Fig. 9a shows the relationship between the fusion enthalpy of the eutectic and the ice under the presence and absence of C8Glu. It was examined based on the each DSC chart in Fig. 8. In Fig. 9a, two dotted lines represent the corresponding results obtained under without C8Glu, that is, the result of $\mathrm{NaCl}$ solution. Quantitative analysis of the two peaks was conducted as shown in Fig. 9b.

As can be seen from Fig. 9a, it was confirmed that when the amphiphilic sugar derivative, C8Glu, was not present, the fusion enthalpy of ice decreased and that of the eutectic increased linearly with the concentration of $\mathrm{NaCl}$. This result was interpreted that formation of the eutectic was regulated by $\mathrm{NaCl}$ concentration. 
On the other hand, when C8Glu was present in the system at the concentration of $10 \mathrm{wt} \%$ of water mass, the fusion enthalpy of eutectic was zero in a region of Group (I), and that of the ice slowly decreased compared with that in other Groups. It meant that a part of water was retained as non-freezing water, which could not be attributed to the formation of ice even below $-100{ }^{\circ} \mathrm{C}$. In the Group (II) and (III) in Fig. 9a, dotted and solid two lines were depicted in parallel. It signified that formation of a definite amount of eutectic was depressed by C8Glu in the system regardless of $\mathrm{NaCl}$ concentration.

In this section, C8Glu clearly depicted the conception on the additive effect of amphiphilic sugar derivatives for eutectic formation. Some other sugar derivatives such as C12Raffinose, C12Sucrose, C12Maltose, C8Mannose, C8Gulose appeared in the following section also exhibited a similar behavior. From their nonspecific behavior, it was concluded that the characteristics that amphiphilic sugar derivatives possess the ability to depress the formation of eutectic was general one.

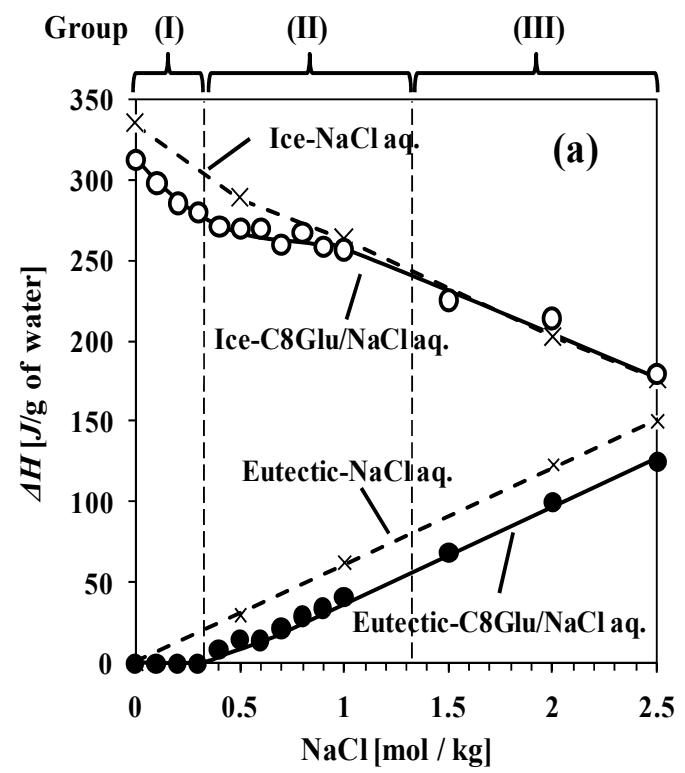

(b)

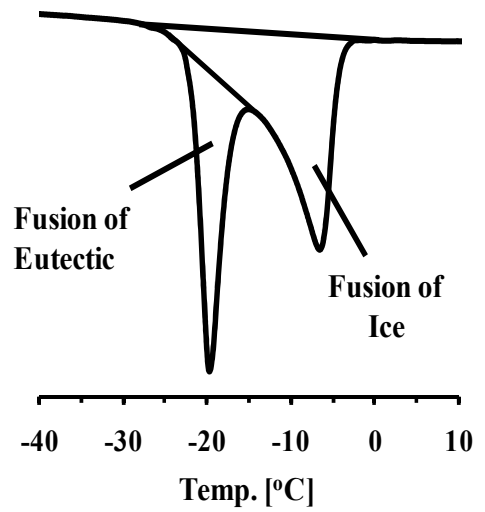

Fig. 9. Analysis of melting enthalpies in $\mathrm{NaCl}$ / water system with and without C8Glu.

(a) Fusion enthalpies of ice (above) and eutectic (below). (b) Calculated enthalpy areas of ice fusion and eutectic fusion.

\subsection{Simultaneous XRD-DSC analysis}

The depression effect of another amphiphilic sugar derivative for eutectic formation was studied to clarify its mechanism in detail. Here, C12Raf was used as a specimen instead of C8Glu. Scheme 2 shows its chemical structure and synthetic route.

Fig. 10 indicates DSC thermograms of $\mathrm{C} 12 \mathrm{Raf} / \mathrm{NaCl} /$ water ternary systems in the thawing process. The sample of C12Raf solution was prepared in a same concentration; C12Raf to water $=1: 3$ [weight ratio]. The molality of two $\mathrm{NaCl}$ solutions were $1.0 \mathrm{~mol} / \mathrm{kg}$ and 2.5 
mol/kg in Fig. 10(a) and (b). The appearance of the chart in Fig. 10(a) was similar to that of C8Glu system of Group (I) stated in Fig. 8 and Fig. 10(b) was to that of Group (II), respectively, although their sample situations were different in terms of their constituent and concentration.
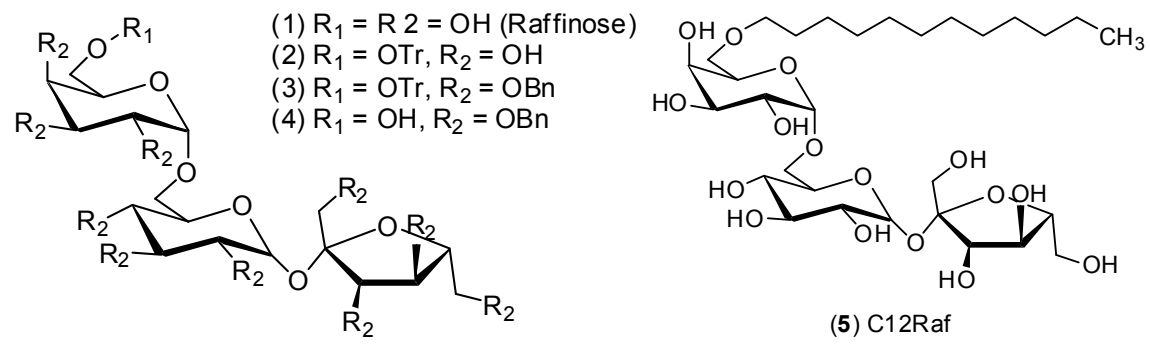

(5) C12Raf

Scheme 2. Chemical structure and synthesis of 6"-O-dodecylraffinose (5: C12Raf).

C12Raf was synthesized from raffinose in four steps of tritylation, benzylation, detritylation, dodecylation and subsequent debenzylation, as shown in Scheme 2.

In two DSC charts in Fig. 10, an irregular deviation pointed out by an arrow was recognized on the base line. It appeared at $-40{ }^{\circ} \mathrm{C}$ in (a) and $-50{ }^{\circ} \mathrm{C}$ in (b). They were corresponding to a glass transition at this temperature, respectively. Fig. 10(a) suggested that the unfrozen phase was converted into the glass state after ice was built up during the cooling process. The exothermic peak appeared at around $-40^{\circ} \mathrm{C}$ during the heating process, in Fig. 10(b). It indicated that the devitrification conclusively occurred immediately after the glass transition. The unfrozen phase in a ternary sample became a glass state by freezecondensation during a cooling process at $-70^{\circ} \mathrm{C}$. Consequently, the formation of eutectic has been depressed under the kinetics.

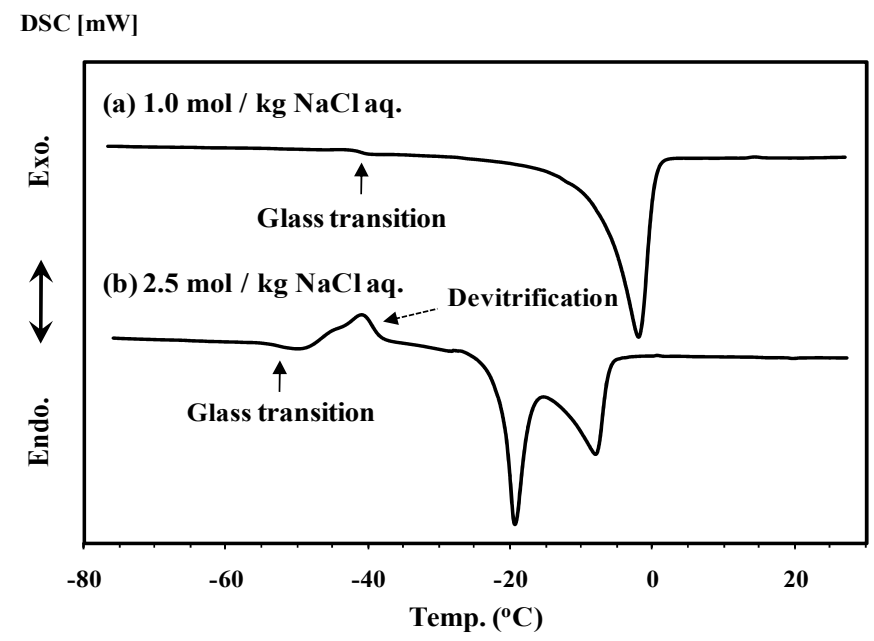

Fig. 10. DSC thermograms of $\mathrm{C} 12 \mathrm{Raf} / \mathrm{NaCl} /$ water systems in the thawing process.

The weight ratio between C12Raf and water was constant (C12Raf : water $=25: 75 \mathrm{wt} \%)$. NaCl concentration was as follows; (a) $1.0 \mathrm{~mol} / \mathrm{kg}$ of pure water and (b) $2.5 \mathrm{~mol} / \mathrm{kg}$ of pure water. 
$\mathbf{a}$

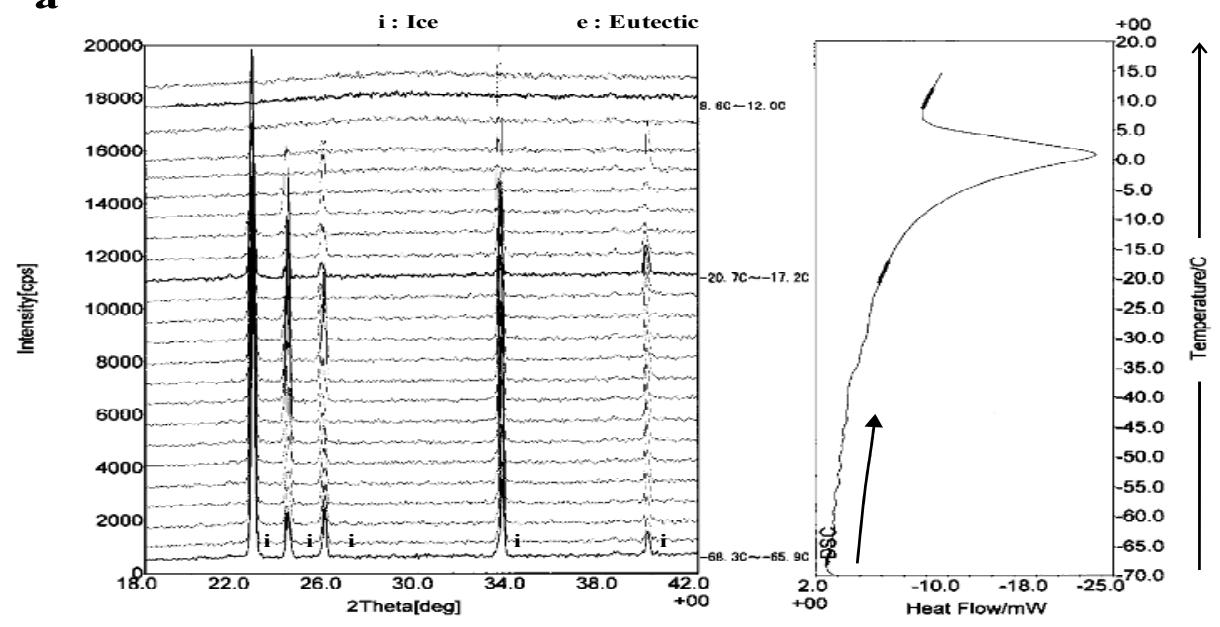

b

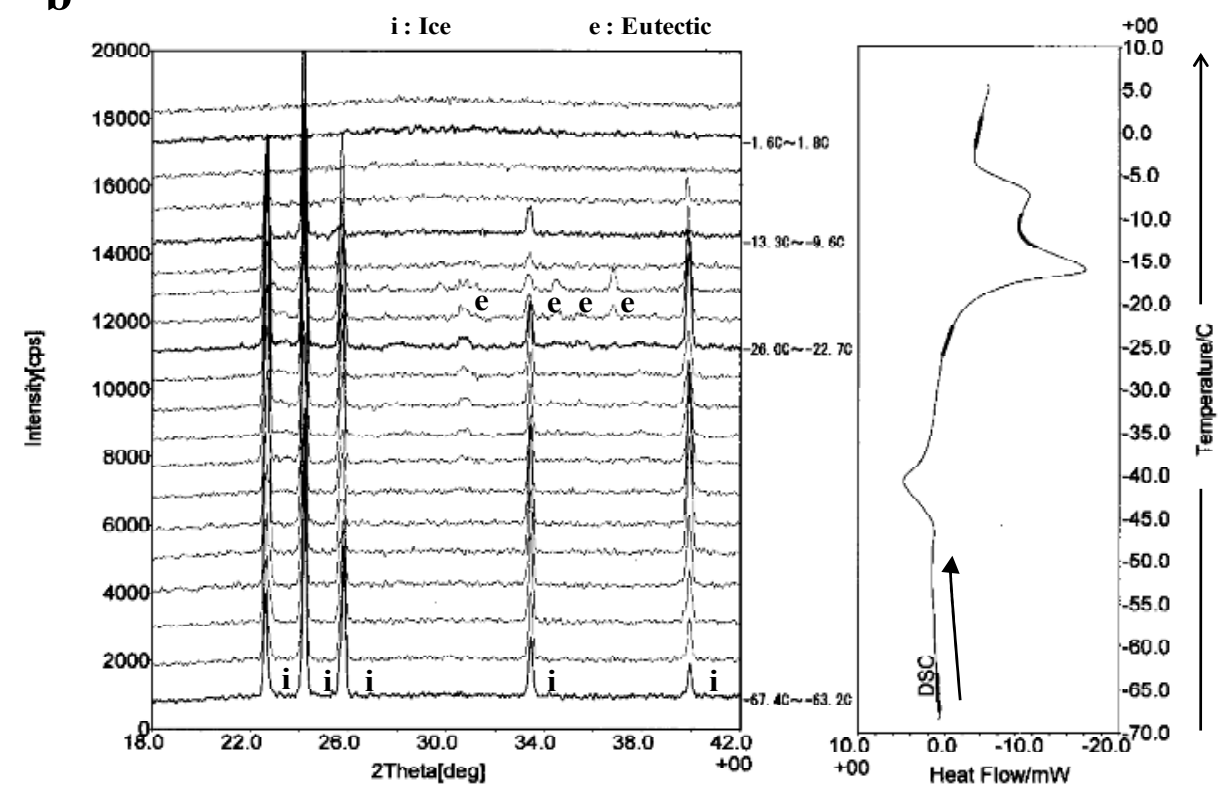

Fig. 11. Simultaneous XRD-DSC measurement of the thawing process in C12Raf/ $\mathrm{NaCl} /$ water systems.

C12Raf and water was constant (C12Raf : water $=25: 75 \mathrm{wt} \%) . \mathrm{NaCl}$ concentration was as follows; (a) $1.0 \mathrm{~mol} / \mathrm{kg}$ of pure water and (b) $2.5 \mathrm{~mol} / \mathrm{kg}$ of pure water. Apparatus; XRDDSC II (RIGAKU) was used for measurement. Details of this apparatus are found elsewhere (Arii, T.; Kishi, A. \& Kobayashi, Y. (1999). Kishi, A.; Otsuka, M. \& Matsuda, Y. (2002).) Measurement conditions were as follows; 1 . Cooled to $-70{ }^{\circ} \mathrm{C}$ at $-6{ }^{\circ} \mathrm{C} / \mathrm{min}$. 2. Heated to $15{ }^{\circ} \mathrm{C}$ at $2{ }^{\circ} \mathrm{C} / \mathrm{min}$. e, eutectic diffraction peak; i, ice diffraction peak. 
The two samples in Fig. 10, (a) and (b) were examined by simultaneous XRD-DSC measurement. The results were summarized in Fig. 11. DSC chart of Fig. 11(a) showed only one peak due to the fusion of ice. The XRD-DSC chart demonstrated that when the system was cooled until $-70{ }^{\circ} \mathrm{C}$ the ice was definitely formed. Five peaks at $2 \theta=22.5,24.1,25.8,33.4$, 39.8 [deg] were observed during the experiment. All diffraction peaks could be indexed to the standard hexagonal ice (Nishimoto, Y.; Kaneki, Y. \& Kishi, A. (2004).). These peaks disappeared in the region above $0^{\circ} \mathrm{C}$. No peaks other than the ice were observed throughout the each and every temperature examined. It meant that formation of eutectic was completely depressed by $\mathrm{C} 12 \mathrm{Raf}$ at this $\mathrm{NaCl}$ concentration.

Fig. 11(b) showed the XRD-DSC profiles for the sample prepared under a concentrated $\mathrm{NaCl}$ solution, its molality was $2.5 \mathrm{~mol} / \mathrm{kg}$. Highly meaningful results could be obtained by this method. In a cooler region of temperature between $-67{ }^{\circ} \mathrm{C} \sim-30{ }^{\circ} \mathrm{C}$, five peaks due to a hexagonal system of ice appeared at the same $2 \theta$ angles as in Fig.11(a) in a similar manner. At higher temperature after an exothermic peak appeared at about $-40.5^{\circ} \mathrm{C}$, four peaks newly emerged at $2 \theta=30.7,34.5,35.8,36.8$ [deg]. This peak pattern was in fair consistent with the authentic diffraction data of the eutectic, $\mathrm{NaCl} \cdot 2 \mathrm{H}_{2} \mathrm{O}$ / ice (Kajiwara, K.; Motegi, A. \& Murase, N. (2001).). That is, it was found that the devitrification induced the formation of eutectic after the occurrence of the glass transition at $-50{ }^{\circ} \mathrm{C}$. These four peaks were extinguished accompanied by fusion of the eutectic above $-21{ }^{\circ} \mathrm{C}$. Further increment of temperature also resulted in a complete disappearance of the diffractive peaks of the ice.

These experiments were able to be summarized as follows; in a circumstance of dilute $\mathrm{NaCl}$ solution such as Group (I), the formation of eutectic was depressed by amphiphilic sugar derivatives such as C8Glu and C12Raf during both cooling and heating processes. On the other hand, in a medium concentrated $\mathrm{NaCl}$ solution designated Group (II), the formation of eutectic was restricted during the cooling process, but during the heating process, the devitrification induced the formation of eutectic after the occurrence of the glass transition. As could be seen from the Fig. 10, both in Group (I) and (II), the glass transition was confirmed during the heating process.

The glass formation plays a main role for this phenomenon, such as depression of eutectic formation. Non-amphiphilic free sugars and certain polymers have properties to change an aqueous solution into the glass state and inhibit the eutectic formation (Nicolajsen, H. \& Hvidt, A. (1994). Izutsu, K.; Yoshioka, S. \& Kojima, S. (1995). Kajiwara, K.; Motegi, A. \& Murase, N. (2001).). The amphiphilic sugars would exhibit more effective capabilities except for depressing the formation of eutectic because of the versatile characteristics based on their interface active properties.

\subsection{Effects of hydrophobic length and sugar structure on inhibition of eutectic formation}

Two different kinds of sugars with a hydrophobic group or without it were examined to make clear the influence of the hydrophobic groups on the inhibition effect for eutectic formation. In other word, the effect of formation of aggregate of the specimen was examined. The results were summarized in Fig. 12. 6"-O-Dodecyraffinose (C12Raf) and 6'-O-dodecanoylsucrose (C12Suc) were used as specimens. The former linked the hydrophobic dodecyl group through ether linkage and the latter combined it through dodecanoyl ester linkage. 
We separately confirmed their aggregation behavior using an automatic digital Kyowa Surface Tensiometer, CBVP-3 (Kyowa Kaimen Kagaku Ltd) by Wilhelmy-plate method. It was found that these amphiphilic sugar derivatives, C12Raf and C12Suc, had a critical micelle concentration $(\mathrm{cmc})$ in pure water at $0.49 \mathrm{mM}$ and $0.16 \mathrm{mM}$, respectively under room temperature. It meant these sugars formed the aggregate in the measuring conditions.
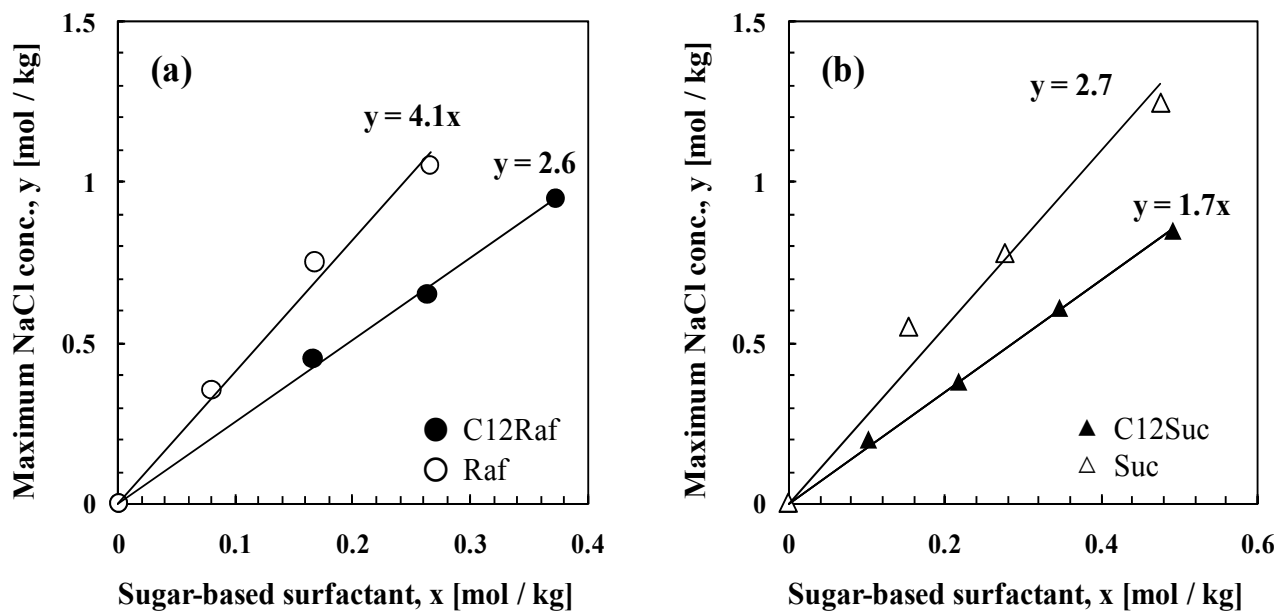

Fig. 12. $\mathrm{NaCl}$ concentration range of Group (I) with various concentrations of sugar-based amphiphiles. (a) C12Raf and Raf. (b) C12Suc and Suc.

Fig. 12 demonstrated relationships between the inhibited maximum $\mathrm{NaCl}$ concentration and the amphiphilic sugar concentration of the system in terms of two kinds of sugar. The ordinate suggested the maximum concentration of $\mathrm{NaCl}$ where the formation of eutectic was completely inhibited corresponding to the concentration of the sugar on the abscissa. This $\mathrm{NaCl}$ concentration refers to the boundary one between Group (I) and (II) shown in Fig. 9(a).

As can be seen from Fig. 12, depression ability for the formation of eutectic was clearly proportional to concentration of the sugar. The amphiphilic trisaccharide (C12Raf) and disaccharide (C12Suc) showed smaller depression ability than the corresponding nonamphiphilic free sugar. Its ratio was about 0.63 for all sugars examined.

The slope of the graph in Fig. 12 suggests the magnitude of the depression ability expressed in units per sugar molality. Fig. 13 showed the comparison of various kinds of sugars on the depression effect for eutectic formation. Amphiphilic glucose (C8Glu), mannose (C8Man) and gulose (C8Gul) are monosaccharide, sucrose (C12Suc) and maltose (C12Mal) are disaccharides, and raffinose (C12Raf) is trisaccharide. As can be seen from Fig. 13, the depression ability for the formation of eutectic of the sugar derivatives was proportional to the number of saccharide unit that constituted the hydrophilic part of the amphiphiles. The formation of eutectic made from about $0.8 \sim 0.9$ molality of $\mathrm{NaCl}$ solution was inhibited by a unit molality of the sugar derivative per single unit of the 
saccharide in a proportional manner. In contrast to this, the epimeric isomerism and the structural isomerism between aldose and ketose gave little influence on the capability of inhibition of eutectic formation.

In Group (I) region, the depression effect for the eutectic formation resulted from the vitrification of an unfrozen aqueous phase during the cooling process. $T_{\mathrm{g}}$ of anhydrous amphiphilic sugar derivatives of which the number of sugar unit are different were as follows: C8Glu $=11.2{ }^{\circ} \mathrm{C}$ (Ogawa, S.; Asakura, K \& Osanai, S. (2010).); $\mathrm{C} 8 \mathrm{Mal}=50.4{ }^{\circ} \mathrm{C}$ (Kocherbitov, V. \& Söderman, O. (2004).; C12Maltotrioside $=100{ }^{\circ} \mathrm{C}$ (Ericsson, C. A.; Ericsson, L. C. \& Ulvenlund, S. (2005).)). As can be seen from this, the $T_{\mathrm{g}}$ of the sugar derivatives increased as the number of sugar unit increased. It was confirmed that the facility making vitrification was closely associated with the number of the sugar per a unit volume of the system or density of it.
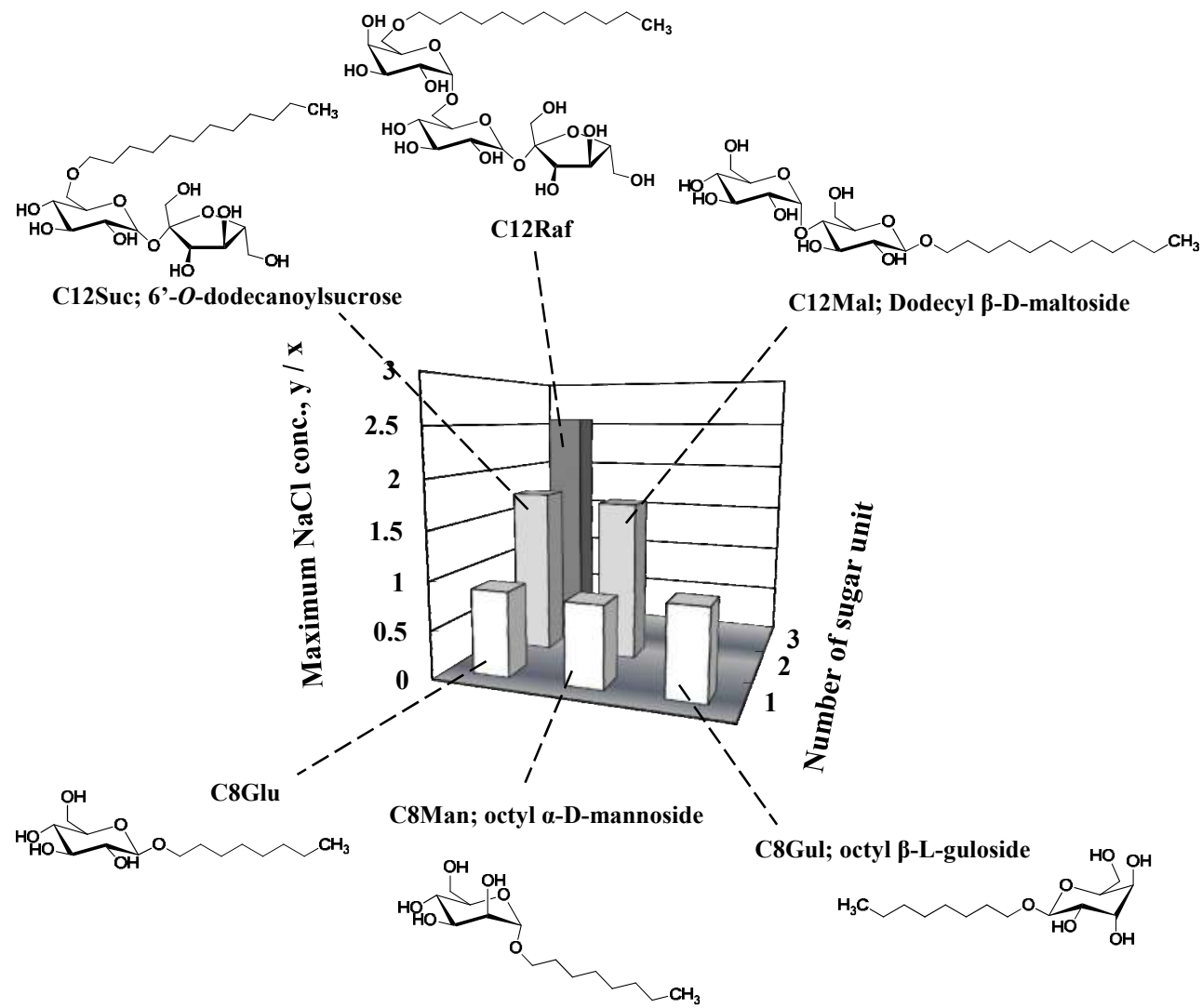

Fig. 13. Comparison of inhibition effect on eutectic formation with sugar structure.

Material; C12Suc, C8Man, C8Gul, and C12Mal were prepared according to published procedures (Ferrer, M.; Cruces, M. A.; Bernabé, M., Ballesteros, A. \& Plou, F. J. (1999). Bryan, M. C.; Plettenburg, O.; Sears, P.; Rabuka, D.; Wacowich-Sgarbi, S. \& Wong, C.-H. (2002). ). 


\section{Conclusion}

Although sugar-based surfactants possess extraordinarily high $T_{\mathrm{g}}$ in an anhydrous state, little is known about the actual application for its excellent glass forming ability. So far as we, authors know, this is the first attempt to apply it in aqueous system and description on it.

In this chapter, we presented the fundamental behavior of glass formation of sugar-based surfactant/water binary system and the inhibition effects of the sugar-based amphiphiles on the formation of eutectic that caused a lot of damage to a variety of bio-organisms from cells to proteins.

In Section 2, the outline of the glass transition behavior of C8Glu, which is one of the representative sugar-based surfactant, and water mixture system was described and summarized. It was clarified the formation of "lyotropic liquid crystal glass" generated from the liquid crystal such as cubic (Q) and lamella (L) in this system. The experimental data for $T_{\mathrm{g}}$ of the lyotropic liquid crystal glass were in fair agreement with the theoretical values proposed as "original" equation by Couchman-Karasz. The peculiar behavior of the system observed through the change of specific heat $\left(\Delta C_{\mathrm{p}}\right)$ during the glass transition and enthalpy $(\Delta H)$ of the phase transition from lamella to isotropic solution or fused liquid was discussed from the standpoint of the permeability of water molecule in the bimolecular membrane structure.

In Section 3, we mentioned the key aspects of the relationships between the inhibiting effect of the sugar-based surfactants and the generating of eutectic in the system. It was also confirmed that increasing saccharide unit of sugar-based surfactant induced an excellent inhibiting effect to the formation of eutectic. Although we focused the increment of the inhibiting power for the formation of eutectic on the introduction of hydrophobic group into the free sugar, the resulted sugar-based surfactant showed only 0.63 times ability for it comparing with the original free sugar.

Because the sugar-based surfactants possess not only the glass forming ability but also the interface active property in the same time, we could expect the possibility that these surfactants show some useful characteristic which could not be obtained by the ordinary free sugars. For example, various kinds of surfactant exhibit abilities that they can depress the deactivation of the protein during the freezing and thawing (Chang, B. S.; Kendrick, B. S. \& Carpenter, J. F. (1996). Hillgren, A.; Lindgren, J. \& Aldén, M. (2002).). But some surface active agents do not always show their contribution to maintain activities of the water soluble proteins such as LDH (Lactate Dehydrogenase) and $\beta$-Galactosidase in the freeze-drying treatment. In contrast to this, when a little amount of a certain sugar derivative was added to a system, it exhibited excellent effects for appreciable retention of the protein activities not only during freeze-thawing but also during freeze-drying processes (Izutsu, K.; Yoshioka, S. \& Terao, T. (1993, 1994). Izutsu, K.; Yoshioka, S. \& Kojima, S. (1995).).

It has been well known that carbohydrates or sugars are materials that can easily form glass state. (Dave, H.; Gao, F.; Lee. J.-H.; Liberatore, M.; Ho, C.-C. \& Co, C. C. (2007).). The sugarbased surfactants could be considered as excellent multiple function surfactants, because 
they have two representative properties of the glass forming and the interface activity. Their application in an aqua-system expands its availability in the fields of foods, medicine and functional materials. Although they have the potential to play an advisable role, their application in a multicomponent system remains underdevelopment state. Under the current situation, the sugar-based surfactant has been applied in the bio-science fields, such as a preservation agent of proteins by freeze-drying method, a solubilizing agent for the preparation of reconstituted protein etc.

We expect that the research mentioned here would be further studied and contribute to their practical application of the sugar-based surfactants including the analytical development on the physico-chemical properties.

\section{Acknowledgment}

All of this study was carried out at "OleoScience Laboratory" in Faculty of Science and Technology, Keio University, Yokohama, JAPAN.

\section{References}

Amim, J.; Kawano, Y. \& Petri, D. F. S. (2009). Thin Films of Carbohydrate Based Surfactants and Carboxymethylcellulose Acetate Butyrate Mixtures: Morphology and Thermal Behavior, Materials Science and Engineering C-Biomimetic and Supramolecular systems, Vol.C29, No.2, (March 2009), pp. 420-425 ISSN 09284931

Andersson, B. \& Olofsson, G. (1987). Differential Scanning Calorimetric Study of PhaseChanges in Poly(ethylene glycol) Dodecyl Ether-Water Systems, Colloid \& Polymer Science, Vol.265, No.4, pp.318-328, ISSN 030-402X

Arii, T.; Kishi, A. \& Kobayashi, Y. (1999). A New Simultaneous Apparatus for X-ray Diffractometry and Differential Scanning Calorimetry (XRD-DSC), Thermochimica Acta, Vol.325, No.2, (January 1999), pp. 151-156, ISSN 0040-6031

Auvray, X.; Petipas, C. \& Anthore, R. (1995). X-ray Diffraction Study of the Ordered Lyotropic Phases Formed by Sugar-Based Surfactants, Langmuir, Vol.11, No.2, (February 1995), pp. 433-439, ISSN 0743-7463

Bonicelli, M. G.; Ceccaroni, G. F. \& La Mesa, C. (1998). Lyotropic and Thermotropic Behavior of Alkylglucosides and Related Compounds, Colloid and Polymer Science, Vol.276, No.2, (Feburary 1998), pp. 109-116, ISSN 0303-402X

Boyd, B. J.; Drummond, C. J.; Krodkiewska, I. \& Grieser, F. (2000). How Chain Length, Headgroup Polymerization, and Anomeric Configuration Govern the Thermotropic and Lyotropic Liquid Crystalline Phase Behavior and the Air-Water Interfacial Adsorption of Glucose-Based Surfactants, Langmuir, Vol.16, No.19, (September 2000), pp. 7359-7367, ISSN 0743-7463

Blond, G.; Simatos, D.; Catté, M.; Dussap, C. G.; Gros, J. B. (1997). Modeling of the WaterSucrose State Diagram Below 0 degrees C, Carbohydrate Research, Vol.298, No.3, (March 1997), pp. 139-145, ISSN 0008-6215 
Bryan, M. C.; Plettenburg, O.; Sears, P.; Rabuka, D.; Wacowich-Sgarbi, S. \& Wong, C.-H. (2002). Saccharide Display on Microtiter Plates, Chemistry \& Biology, Vol.9, No.6, (June 2002), pp. 713-720, ISSN 1074-5521

Chang, B. S.; Kendrick, B. S. \& Carpenter, J. F. (1996). Surface-Induced Denaturation of Proteins during Freezing and its Inhibition by Surfactants, Journal of Pharmaceutical Sciences, Vol.85, No.12, (December 1996), pp. 1325-1330, ISSN 0022-3549

Chen, N. J.; Morikawa, J. \& Hashimoto, T. (2005). Effect of Amino Acids on the Eutectic Behavior of $\mathrm{NaCl}$ Solutions Studies by DSC, Cryobiology, Vol.50, No.3, (June 2005), pp. 264-272, ISSN 0011-2240

Chen, Y.-H. \& Cui, Z. (2006). Effect of Salts on the Freezing Denaturation of Lactate Dehydrogenase, Food and Bioproducts Processing, Vol.84, No.C1, (March 2006), pp. 44-50, ISSN 0960-3085

Couchman, P. R. (1978). Compositional Variation of Glass-Transition Temperatures. 2. Application of Thermodynamic Theory to Compatible Polymer Blends, Macromolecules, Vol.11, No.6, (November 1978), pp. 1156-1161, ISSN 0024-9297

Couchman, P. R. \& Karasz, F. E. (1978). Classical Thermodynamic Discussion of Effect of Composition on Glass-Transition Temperatures, Macromolecules, Vol.11, No.1, (January 1978), pp. 117-119, ISSN 0024-9297

Dave, H.; Gao, F.; Lee. J.-H.; Liberatore, M.; Ho, C.-C. \& Co, C. C. (2007). Self-Assembly in Sugar-Oil Complex Glasses, Nature Materials, Vol.6, No.4, (April 2007), pp. 287290, ISSN 1476-1122

Dörfler, H.-D. \& Göpfert, A. (1999). Lyotropic Liquid Crystals in Binary Systems n-Alkyl Glycosides/Water, Journal of Dispersion Science and Technology, Vol.29, No.1-2, pp. 35-58, ISSN 0193-2691

Drummond, C. J.; Fong, C.; Krodkiewska, I.; Boyd, B. J. \& Baker, I. J. A. (2003). 3 Sugar Fatty Acid Esters, In: Novel Surfactants/114, Edited by Holmberg, K., pp. 95-128, CRC Press, ISBN 978-0-203-91173-0, Marcel Dekker, New York

Ericsson, C. A.; Ericsson, L. C.; Kocherbitov, V.; Söderman, O. \& Ulvenlund, S. (2005). Thermotropic Phase Behaviour of Long-chain Alkylmaltosides, Physical Chemistry Chemical Physics, Vol.7, No.15, (June 2005), pp. 2970-2977, ISSN 14639076

Ericsson, C. A.; Ericsson, L. C. \& Ulvenlund, S. (2005). Solid-state Behaviour of Dodecylglycosides, Carbohydrate Research, Vol.340, No.8, (June 2005), pp. 1529-1537, ISSN 0008-6215

Ferrer, M.; Cruces, M. A.; Bernabé, M., Ballesteros, A. \& Plou, F. J. (1999). Lipase-Catalyzed Regioselctive Acylation of Sucrose in Two-Solvent Mixtures, Biotechnology and Bioengineering, Vol.65, No.1, (October 1999), pp. 10-16, ISSN 0006-3592

Fong, C.; Weerawardena, A.; Sagnella, S. M.; Mulet, X.; Krodkiewska, I.; Chong, J. \& Drummond, C. J. (2011). Monodisperse Noninonic Isoprenoid-Type Hexahydrofarnesyl Ethylene Oxide Surfactants: High Throughput Lyotropic Liquid Crystalline Phase Determination, Langmuir, Vol.27, No.6, (March 2011), pp. 2317-2326, ISSN 0743-7463 
Fukada, K.; Matsuzaka, Y.; Fujii, M.; Kato, T. \& Seimiya, T. (1998). Phase Behavior and Lyotropic-Liquid Crystal Structure of Alkyltrimethylammonium bromide-Water Mixtures around Freezing Temperature of Water, Thermochimica Acta, Vol.308, No.1-2, pp.159-164, ISSN 0040-6031

Gill, I. \& Valivety, R. (2000a). Monosaccharide-Alkyl Glycoside Glass Phases: Plasticization with Hydrophilic and Hydrophobic Molecules, Angewandte Chemie International Edition, Vol.39, No.21, (November 2000), pp.3801-3804, ISSN 1433-7851

Gill, I. \& Valivety, R. (2000b). Enzymatic Glycosylation in Plasticized Glass Phases: A Novel and Efficient Route to O-Glycosides, Angewandte Chemie International Edition, Vol.39, No.21, (November 2000), pp. 3804-3808., ISSN 1433-7851

Goel, R.; Anderson, K.; Slaton, J.; Schmidlin, F.; Vercellotti, G.; Belcher, J. \& Bischof, J. C. (2009). Adjuvant Approaches to Enhance Cryosurgery, Journal of Biomechanical Engineering, Vol.131, No.7, (July 2009), pp. 074003-1-11, ISSN 0148-0731

Han, B. \& Bischof, J. C. (2004). Direct Cell Injury Associated with Eutectic Crystallization During Freezing, Cryobiology, Vol.48, No.1, (February 2004), pp. 8-21, ISSN 00112240

Häntzschel, D.; Schulte, J.; Enders, S. \& Quitzsch, K. (1999). Thermotropic and Lyotropic Properties of n-Alkyl-beta-D-Glucopyranoside Surfactants, Physical Chemistry Chemical Physics, Vol.1, No.5, (March 1999), pp. 895-904, ISSN 1463-9076

Hato, M.; Minamikawa, H. \& Kato T. (2007). Chapter 10 Sugar-Based Surfactants with Isoprenoid-Type Hydrophobic Chains: Physicochemical and Biophysical Aspects, In: Novel Surfactants/143, Edited by Ruiz, C. C., pp. 361-411, CRC Press, ISBN 978-14200-5166-7, Taylor \& Francis Group, Baco Raton

Heber, U. Tyankova, L. \& Santariu, K. A. (1971). Stabilization and Inactivation of Biological Membranes during Freezing in the Presence of Amino Acids, Biochmica et Biophysica Acta, Vol.241, No.2, (August 1971), pp. 578-592, ISSN 0006-3002

Hill, K. LeHen-Ferrenbach, C. (2007). 1 Sugar-Based Surfactants for Consumer Products and Technical Applications, In: Sugar-Based Surfactants/143, Edited by Ruiz, C. C., pp. 120, CRC Press, ISBN 978-1-4200-5166-7, Taylor \& Francis Group, Baco Raton

Hill, K. \& Rhode, O. (1999). Sugar-Based Surfactants for Consumer Products and Technical Applications, Fett/Lipid, Vol.101, No.1, (January 1999), pp. 25-33, ISSN 0931-5985

Hillgren, A.; Lindgren, J. \& Aldén, M. (2002). Protection Mechanism of Tween 80 During Freeze-Thawing of a Model Protein, LDH, International Journal of Pharmaceutics, Vol.237, No.1-2, (April 2002), pp.57-69, ISSN 0378-5173

Hoffmann, B.; Milius, W.; Voss, G.; Wunschel, M.; van Smaalen, S.; Diele, S. \& Platz G. (2000). Crystal Structures and Thermotropic Properties of Alkyl a-Dglucopyranosides and Their Hydrates, Carbohydrate Research, Vol.323, No.1-4, (January 2000), pp. 192-201, ISSN 0008-6215

Hoffmann, B. \& Platz, G. (2001). Phase and Aggregation Behaviour of Alkylglycosides, Current Opinion in Colloid \& Interface Science, Vol.6, No.2, (April 2001), pp.171-177, ISSN 1359-0294 
Hvidt, A. \& Borch, K. (1991). NaCl- $\mathrm{H}_{2} \mathrm{O}$ Systems at Temperatures Below $273 \mathrm{~K}$, Studied by Differential Scanning Calorimetry, Thermochimica Acta, Vol.175, No.1, (February 1991), pp. 53-58 ISSN 0040-6031

Imura T.; Hikosaka, Y.; Worakitkanchanakul, W.; Sakai, H.; Abe, M.; Konishi, M.; Minamikawa, H. \& Kitamoto, D. (2007). Aqueous-Phase Behavior of Natural Glycolipid Biosurfactant Mannosylerythritol Lipid A: Sponge, Cubic, and Lamellar Phases, Langmuir, Vol.23, No4, (February) pp.1659-1663, ISSN 07437463

Izutsu, K.; Kadoya, S.; Yomota, C.; Kawanishi, T.; Yonemochi, E. \& Terada, K. (2009). FreezeDrying of Proteins in Glass Solids Formed by Basic Amino Acids and Dicarboxylic Acids, Chemical \& Pharmaceutical Bulletin, Vol.57, No.1, (January 2009), pp.43-48, ISSN 0009-2363

Izutsu, K.; Yoshioka, S. \& Terao, T. (1994). Stabilizing Effect of Amphiphilic Excipients on the Freeze-Thawing and Freeze-Drying of Lactate Dehydrogenase, Biotechnology and Bioengineering, Vol.43, No.11, (May 1994), pp. 1102-1107, ISSN 0006-3592

Izutsu, K.; Yoshioka, S. \& Terao T. (1993). Stabilization of $\beta$-galactosidase by Amphiphilic Additives During Freeze-Drying, International Journal of Pharmaceutics, Vol.90, No.3, (March 1993), pp. 187-194, ISSN 0378-5173

Izutsu, K.; Yoshioka, S. \& Kojima, S. (1995). Effect of Cryoprotectants on the Eutectic Crystallization of $\mathrm{NaCl}$ in Frozen Solutions Studied by Differential Scanning Calorimetry (DSC) and Broad-Line Pulsed NMR, Chemical Pharmaceutical Bulletin, Vol.43, No.10, (October 1995), pp. 1804-1806, ISSN 0009-2363

Izutsu, K.; Yoshioka, S. \& Kojima, S. (1995). Increased Stabilizing Effects of Amphiphilic Excipients on Freeze-Drying of Lactate Dehydrogenase (LDH) by Dispersion into Sugar Matrices, Pharmaceutical Research, Vol.12, No.6, (June 1995), pp.838-843, ISSN 0724-8741

Jensen, R. E.; O’Brien, E.; Wang, J.; Bryant, J.; Ward, T. C.; James, L. T. \& Lewis, D. A. (1998). Characterization of Epoxy-Surfactant Interactions, Journal of Polymer Science Part B: Polymer Physics, Vol.36, No.15, (November 1998), pp. 2781-2792, ISSN 0887-6266

Kajiwara, K.; Motegi, A. \& Murase, N. (2001). Freeze-Thawing Behaviour of Highly Concentrated Aqueous Alkali Chloride-Glucose Systems, CryoLetters, Vol.22, No.5, (September-October 2001), pp. 311-320, ISSN 0143-2044

Kawai, K. \& Suzuki, T. (2007). Stabilizing Effect of Four Types of Disaccharide on the Enzymatic Activity of Freeze-Dried Lactate Dehydrogenase: Step by Step Evaluation from Freezing to Storage, Pharmaceutical Research, Vol.24, No.10, (October 2007), pp. 1883-1890, ISSN 0724-8741

Kishi, A.; Otsuka, M. \& Matsuda, Y. (2002). The Effect of Humidity on Dehydration Behavior of Nitrofurantoin Monohydrate Studied by Humidity Controlled Simultaneous Instrument for X-ray Diffractometry and Differential Scanning Calorimetry (XRD-DSC), Colloids and Surfaces B: Biointerfaces, Vol.25, No.4, (August 2002), pp. 281-291, ISSN 0927-7765 
Kocherbitov, V. \& Söderman, O. (2004). Glassy Crystalline State and Water Sorption of Alkyl Maltosides, Langmuir, Vol.20, No.8, (April 2004), pp. 3056-3061, ISSN 0743-7463

Kocherbitov, V. \& Söderman, O. (2003). Phase Diagram and Physicochemical Properties of the n-Octyl a-D-glucoside/Water System, Physical Chemical Chemical Physics, Vol.5, No.23, (December 2003), pp.5262-5270, ISSN 1463-9076

Kocherbitov, V.; Söderman O. \& Wadsö, L. (2002). Phase Diagram and Thermodynamics of the n-Octyl beta-D-Glucoside/Water System, Journal of Physical Chemistry B, Vol.106, No.11, (March 2002) pp. 2910-2917, ISSN 1520-6106

Koshimoto, C. \& Mazur, P. (2002). The Effect of the Osmolality of Sugar-Containing Media, the Type of Sugar, and the Mass and Molar Concentration of Sugar on the Survival of Frozen-Thawed Mouse Sperm, Cryobiology, Vol.45, No.1, (August), pp. 80-90, ISSN 0011-2240

Loewenstein, A. \& Igner, D. (1991). Deuterium NMR-Studies of n-Octyl alpha and beta-DGlucopyranoside Liquid Crystalline Systems, Liquid Crystals, Vol.10, No.4, (October 1991), pp. 457-466, ISSN 0267-8292

Mollenhauer, A.; Schmitt, J. M.; Coughlan, S. \& Heber U. (1983). Loss of Membrane-Proteins from Thylakoids during Freezing, Bichimica et Biophysica Acta, Vol.728, No.3, (March 1983), pp. 331-338, ISSN 0006-3002

Mullin, J. W. (2001). 4, Phase Equilibria, in Crystallization Fourth Edition, ISBN 0-7506-4833-3, Butterworth-Heinemann, Ocford.

Nibu, Y. \& Inoue, T. (1998a). Solid-Liquid Phase Behavior of Binary Mixture of Tetraethylene Glycol Decyl Ether and Water, Journal of Colloid and Interface Science, Vol.205, No.2, (September 1998a), pp.231-240, 0021-9797

Nibu, Y. \& Inoue, T. (1998b). Phase Behavior of Aqueous Mixtures of Some Polyethylene Glycol Decyl Ethers Revealed by DSC and FT-IR Measurements, Journal of Colloid and Interface Science, Vol.205, No.2, (September 1995), pp.305315, ISSN 0021-9797

Nibu, Y.; Suemori, T. \& Inoue T. (1997). Phase Behavior of Binary Mixture of Heptaethylene Glycol Decyl Ether and Water: Formation of Phase Compound in Solid Phase, Journal of Colloid and Interface Science, Vol. 191, No.1, (July 1997), pp. 256-263, ISSN 0021-9797

Nicolajsen, H. \& Hvidt, A. (1994). Phase Behavior of the System Trehalose-NaCl-Water, Cryobiology, Vol.31, No.2, (April 1994), pp. 199-205, ISSN 0011-2240

Nilsson, F.; Söderman, O. \& Johansson, I. (1996). Physical-Chemical Properties of the nOctyl beta-D-Glucoside/Water System. A Phase Diagram, Self-Diffusion NMR, and SAXS Study, Langmuir, Vol.12, No.4, (February 1996), pp. 902-908, ISSN 0743-7463

Nishimoto, Y.; Kaneki, Y. \& Kishi, A. (2004). Simultaneous XRD-DSC Measurements of Water-2-Propanol at Sub-Zero Temperatures, Analytical Sciences, Vol.20, No.7, (July 2004), pp. 1079-1082, ISSN 0910-6340

Ogawa, S.; Asakura, K. \& Osanai, S. (2010). Glass Transition Behavior of Octyl beta-DGlucoside and Octyl beta-D-Thioglucoside/Water Binary Mixtures, Carbohydrate Research, Vo.345, No.17, (November 2010), pp. 2534-2541, ISSN 0008-6215 
Ogawa, S. \& Osanai, S. (2007). Inhibition Effect of Sugar-based Amphiphiles on Eutectic Formation in the Freezing-Thawing Process of Aqueous $\mathrm{NaCl}$ Solution, Cryobiology, Vol.54, No.2, (April 2007), pp. 173-180, ISSN 0011-2240

Rasmussen, D. H. \& MacKenzie, A. P. (1971). Glass Transition in Amorphous WaterApplication of Measurements to Problems Arising in Cryobiology, Journal of Physical Chemistry, Vol.75, No.7, (April 1971), pp. 967-973, ISSN 00223654

Rybinski, von W. \& Hill, K., Alkyl Polyglycosides-Properties and Applications of a new Class of Surfactants, Angewandte Chemie International Edition, Vol.37, No.10, (June 1998) pp.1328-1345, ISSN 1433-7851

Sakya, P., Seddon, J. M. \& Templer, R. H. (1994). Lyotropic Phase Behavior of n-Octyl-1-Obeta-D-Glucopyranoside and its Thio Derivative n-Octyl-1-S-beta-DGlucopyranoside, Journal De Physiqu II, Vol.4, No.8, (August 1994), pp. 1311-1331, ISSN 1155-4312

Söderberg, I.; Drummond, C. J.; Furlong, D. N.; Godkin, S. \& Matthews, B. (1995). Non-ionic Sugar-Based Surfactants: Self Assembly and Air/Water Interfacial Activity, Colloids and Surfaces A: Physicochemical and Engineering Aspects, Vol. 102, (September 1995), pp.91-97, ISSN 0927-7757

Sugisaki, M.; Suga, H. \& Seki, S. (1968). Calorimetric Study of the Glassy State. IV. Heat Capacities of Glassy Water and Cubic Ice, Bulletin of the Chemical Society of Japan, Vol.41, No.11, (November 1968), pp. 2591-2599, ISSN 0009-2673

Szúts, A.; Pallagi, E.; Regdon, G. Jr; Aigner, Z.; Szabó-Révész, P. (2007). Study of Thermal Behaviour of Sugar Esters, International Journal of Pharmaceutics, Vo. 336, No.2, (May 2007), pp. 199-27, ISSN 0378-5173

Tyankova, L. (1972). Effect of Amino-Acids on Thylakoid Membranes During Freezing as Influenced by Side Chain and Position on the Amino Group, Biochimica et Biophysica Acta, Vo.274, No.1, (July 1972), pp. 75-82, ISSN 0006-3002

Wang, C.-L., Teo, K. Y. \& Han. B. (2008). An Amino Acidic Adjuvant to Augment Cryoinjury of MCF-7 Breast Cancer Cells, Cryobiology, Vol.57, No.1, (August 2008), pp. 52-59, ISSN 0011-2240

Warr, G. G.; Drummond, C. J.; Grieser, F.; Ninham, B. W. \& Evans, D. F. (1986). AqueousSolution Properties of Nonionic n-Dodecyl Beta-D-Maltoside Micelles, Journal of Physical Chemistry, Vol.90, No.19, (September 1986), pp. 4581-4586, ISSN 00223654

Yoshioka, H.; Sorai, M. \& Suga, H. (1983). Heat Capacity of N-p-n-Hexyloxybenzylidene-p'n-butylaniline between 11 and $393 \mathrm{~K}$ : Unusual Glassy Smectic Liquid Crystal, Molecular Crystal \& Liquid Crystal, Vol.95, No.1-2, (November 1982), pp. 11-30, ISSN 0140-6566

Zheng, L. Q.; Suzuki, M. \& Inoue, T. (2002). Phase Behavior of an Aqueous Mixture of Octaethylene Glycol Dodecyl Ether Revealed by DSC, FT-IR, and 13C NMR Measurements, Langmuir, Vol.18, No.6, (March 2002), pp.1991-1998, ISSN 07437463 
Zheng, L. Q.; Suzuki, M.; Inoue, T. \& Lindman, B. (2002). Aqueous Phase Behavior of Hexaethylene Glycol Dodecyl Ether Studied by Differential Scanning Calorimetry, Fourier Transform Infrared Spectroscopy, and 13C NMR Spectroscopy, Langmuir, Vol.18, No.24, (November 2002), pp.9204-9210, ISSN 0743-7463 


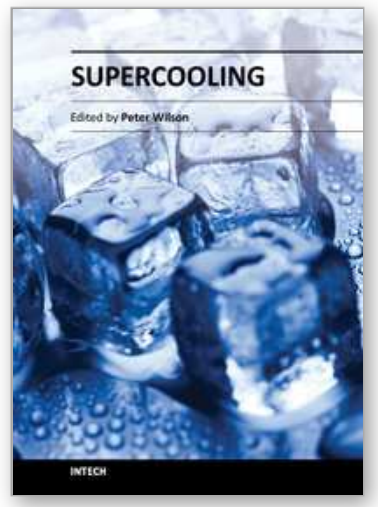

\author{
Supercooling \\ Edited by Prof. Peter Wilson
}

ISBN 978-953-51-0113-0

Hard cover, 134 pages

Publisher InTech

Published online 09, March, 2012

Published in print edition March, 2012

Supercooled liquids are found in the atmosphere, in cold hardy organisms, in metallurgy, and in many industrial systems today. Stabilizing the metastable, supercooled state, or encouraging the associated process of nucleation have both been the subject of scientific interest for several hundred years. This book is an invaluable starting point for researchers interested in the supercooling of water and aqueous solutions in biology and industry. The book also deals with modeling and the formation subsequent dendritic growth of supercooled solutions, as well as glass transitions and interface stability.

\title{
How to reference
}

In order to correctly reference this scholarly work, feel free to copy and paste the following:

Shigesaburo Ogawa and Shuichi Osanai (2012). Glass Transition Behavior of Aqueous Solution of SugarBased Surfactants, Supercooling, Prof. Peter Wilson (Ed.), ISBN: 978-953-51-0113-0, InTech, Available from: http://www.intechopen.com/books/supercooling/glass-transition-behavior-of-aqueous-solution-of-sugar-basedsurfactants

\section{INTECH}

open science | open minds

\section{InTech Europe}

University Campus STeP Ri

Slavka Krautzeka 83/A

51000 Rijeka, Croatia

Phone: +385 (51) 770447

Fax: +385 (51) 686166

www.intechopen.com

\section{InTech China}

Unit 405, Office Block, Hotel Equatorial Shanghai

No.65, Yan An Road (West), Shanghai, 200040, China

中国上海市延安西路 65 号上海国际贵都大饭店办公楼 405 单元

Phone: +86-21-62489820

Fax: +86-21-62489821 
(C) 2012 The Author(s). Licensee IntechOpen. This is an open access article distributed under the terms of the Creative Commons Attribution 3.0 License, which permits unrestricted use, distribution, and reproduction in any medium, provided the original work is properly cited. 